\title{
Yohimbine Depresses Excitatory Transmission in BNST and Impairs Extinction of Cocaine Place Preference Through Orexin-Dependent, Norepinephrine-Independent Processes
}

\author{
Kelly L Conrad', Adeola R Davis ${ }^{2}$, Yuval Silberman', Douglas J Sheffler ${ }^{3,4}$, Angela D Shields', Sam A Saleh ${ }^{3}$, \\ Namita Sen ${ }^{5,6,7}$, Heinrich JG Matthies ${ }^{2}$, Jonathan A Javitch ${ }^{5,6,7}$, Craig W Lindsley ${ }^{3,4}$ and Danny G Winder*, , 2,8,9 \\ 'Department of Molecular Physiology and Biophysics, Vanderbilt University School of Medicine, Nashville, TN, USA; '2Department of Center for \\ Molecular Neuroscience, Vanderbilt University School of Medicine, Nashville, TN, USA; ${ }^{3}$ Department of Pharmacology, Vanderbilt University \\ School of Medicine, Nashville, TN, USA; ${ }^{4}$ Department of Vanderbilt Center for Neuroscience Drug Discovery, Vanderbilt University School of \\ Medicine, Nashville, TN, USA; ${ }^{5}$ Department of Psychiatry, College of Physicians and Surgeons, Columbia University, New York, NY, USA; \\ ${ }^{6}$ Department of Pharmacology, College of Physicians and Surgeons, Columbia University, New York, NY, USA; ${ }^{7}$ Department of Pharmacology, \\ Center for Molecular Recognition, College of Physicians and Surgeons, Columbia University, New York, NY, USA; ${ }^{8}$ Kennedy Center for Research on \\ Human Development, Vanderbilt University School of Medicine, Nashville, TN, USA; ${ }^{9}$ Vanderbilt Brain Institute, Nashville, TN, USA
}

\begin{abstract}
The alpha2 adrenergic receptor ( $\left.\alpha_{2}-A R\right)$ antagonist yohimbine is a widely used tool for the study of anxiogenesis and stress-induced drug-seeking behavior. We previously demonstrated that yohimbine paradoxically depresses excitatory transmission in the bed nucleus of the stria terminalis (BNST), a region critical to the integration of stress and reward pathways, and produces an impairment of extinction of cocaine-conditioned place preference (cocaine-CPP) independent of $\alpha_{2}$-AR signaling. Recent studies show yohimbineinduced drug-seeking behavior is attenuated by orexin receptor I $(O X, R)$ antagonists. Moreover, yohimbine-induced cocaine-seeking behavior is BNST-dependent. Here, we investigated yohimbine-orexin interactions. Our results demonstrate yohimbine-induced depression of excitatory transmission in the BNST is unaffected by alphal-AR and corticotropin-releasing factor receptor-I (CRFR 1 ) antagonists, but is (I) blocked by OxR antagonists and (2) absent in brain slices from orexin knockout mice. Although the actions of yohimbine were not mimicked by the norepinephrine transporter blocker reboxetine, they were by exogenously applied orexin A. We find that, as with yohimbine, orexin A depression of excitatory transmission in BNST is OX,R-dependent. Finally, we find these ex vivo effects are paralleled in vivo, as yohimbine-induced impairment of cocaine-CPP extinction is blocked by a systemically administered $O X, R$ antagonist. These data highlight a new mechanism for orexin on excitatory anxiety circuits and demonstrate that some of the actions of yohimbine may be directly dependent upon orexin signaling and independent of norepinephrine and CRF in the BNST.

Neuropsychopharmacology (20I2) 37, 2253-2266; doi: I0.1038/npp.2012.76; published online 23 May 2012
\end{abstract}

Keywords: norepinephrine; orexin; plasticity; reward; stress; yohimbine

\section{INTRODUCTION}

The widely used pharmacological stressor yohimbine induces relapse to drug- and alcohol-seeking behavior (Shaham et al, 2000; Shalev et al, 2010). In abstinent drugdependent subjects, yohimbine increases anxiety (McDougle et al, 1994) and drug craving (Stine et al, 2002). Yohimbine is thought to act primarily via its inhibition of presynaptic noradrenergic alpha2 adrenergic receptor $\left(\alpha_{2}\right.$-ARs), thereby

\footnotetext{
*Correspondence: Dr DG Winder, Department of Molecular Physiology and Biophysics, Vanderbilt University School of Medicine, Nashville, TN 37232, USA, Tel: + | 615322 ||44, Fax: + | 615322 1462,

E-mail: danny.winder@vanderbilt.edu

Received 13 March 2012; revised 18 April 2012; accepted 19 April 2012
}

increasing norepinephrine levels (Abercrombie et al, 1988; Aghajanian and VanderMaelen, 1982; Starke, 2001). In addition to research using yohimbine as a pharmacological stressor to induce illicit drug- and alcohol-reinstatement (Shaham et al, 2000; Shalev et al, 2010), recent studies demonstrate yohimbine impairs extinction of cocaineconditioned place preference (cocaine-CPP) and self-administration (Davis et al, 2008; Kupferschmidt et al, 2009; Marinelli et al, 2007).

The bed nucleus of the stria terminalis (BNST), a key site for the integration of stress and reward processing, is a critical region mediating the effects of stressors on cocaineseeking behavior (Buffalari and See, 2010; Erb et al, 2001; Leri et al, 2002). In particular, the BNST is critical for yohimbineinduced reinstatement of drug-seeking behavior (Brown et al, 2009; Buffalari and See, 2010). Yohimbine depresses 
excitatory transmission in the adult dorsal BNST (Davis et al, 2008). This finding is paradoxical given that $\alpha_{2}$-AR agonists produce similar actions (Davis et al, 2008; Shields et al, 2009). Further, the effects of yohimbine on both excitatory transmission and extinction of cocaine-CPP are intact in $\alpha_{2 \mathrm{~A}}$-AR knockout mice and not fully mimicked by the $\alpha_{2}$-AR antagonist atipamezole, suggesting that they are mediated by targets other than $\alpha_{2}$-ARs (Davis et al, 2008).

Yohimbine-induced reinstatement of cocaine-seeking behavior requires orexin 1 receptor $\left(\mathrm{OX}_{1} \mathrm{R}\right)$ activity (Buffalari and See, 2010; Zhou et al, 2011). The orexin system was first described in the late 1990s, when the orexin neuropeptides were shown to be important in feeding and arousal-related behaviors (de Lecea et al, 1998; Sakurai et al, 1998). Since then, studies have demonstrated an important role for the orexin system in anxiety and reward-related behaviors (Boutrel et al, 2005; Dayas et al, 2008; Espana et al, 2010; Harris et al, 2005; Johnson et al, 2010; Lawrence et al, 2006; Richards et al, 2008; Zhou et al, 2011). The BNST receives dense orexinergic inputs (Baldo et al, 2003) and has a high density of $\mathrm{OX}_{1} \mathrm{R}$ mRNA and protein expression (Hervieu et al, 2001; Marcus et al, 2001). Further, anxietylike behaviors in rodents are dependent on BNST $\mathrm{OX}_{1} \mathrm{R}$ signaling (Johnson et al, 2010).

Here, we investigated the role of OxRs in the actions of yohimbine on excitatory transmission in the BNST, and on extinction of cocaine-CPP. These studies reveal that yohimbine recruits an Ox1R-dependent depression of excitatory transmission in BNST, and that a systemically administered $\mathrm{OX}_{1} \mathrm{R}$ antagonist blocks yohimbinemediated impairment of extinction of cocaine-CPP. Taken together, our results suggest yohimbine acts in a norephinephrine-independent manner to recruit orexin signaling and impact excitatory transmission in the adult BNST, demonstrating a novel role for orexin $\mathrm{A}$ as an inhibitory neuropeptide on excitatory input in anxiety and reward circuits. Finally, we identify a role for orexin in mediating the effects of the stressor yohimbine on cocaine extinction.

\section{SUBJECTS AND METHODS}

\section{Subjects}

Experiments on C57BL/6J mice were conducted using males aged 8-12 weeks obtained from the Jackson Laboratory (Bar Harbor, ME). Male $\alpha_{2 \mathrm{~A}}$ AR KO mice were generated as previously described (Altman et al, 1999) and backcrossed onto a C57BL/6J genetic background for a minimum of eight generations. Mice were housed on a 12-h light/dark cycle in groups of two to five with ad libitum access to food and water. Testing commenced at least 1 week after acclimation to the facilities. All procedures were approved by the Vanderbilt University Animal Care and Use Committees and were in accordance with the Animal Welfare Act. The number of mice used is reported in the figure legends.

\section{Mouse Drug Treatment}

All drugs were administered intraperitoneally (i.p.) in a volume of $10 \mathrm{ml} / \mathrm{kg}$ body weight. For the cocaine-CPP experiments: vehicle $(0.9 \%$ sterile saline $)$ and cocaine $(20 \mathrm{mg} / \mathrm{kg}$; i.p.) in vehicle were administered immediately before placement in the CPP apparatus.

For the cocaine-CPP extinction experiments: yohimbine in distilled $\mathrm{H}_{2} \mathrm{O}(5 \mathrm{mg} / \mathrm{kg}$; i.p.; $30 \mathrm{~min}$ prior) or vehicle (30 min prior) or SB-334867 (15 mg/kg; i.p. $1 \mathrm{~h}$ prior) in $1 \%$ (w/v) (2-hyroxypropyl)- $\beta$-cyclodextrin/10\% dimethyl sulfoxide (DMSO) in sterile water (termed DMSO-vehicle; $1 \mathrm{~h}$ prior) were administered for extinction sessions 1-5. SB334867 has been found to reach peak plasma and brain concentrations at $30 \mathrm{~min}$ post injection and maintains good exposure for up to $4 \mathrm{~h}$ (Porter et al, 2001). The dose of $5 \mathrm{mg} /$ $\mathrm{kg}$ yohimbine was selected based on previous reports that this dose increases plasma corticosterone levels (Banihashemi and Rinaman, 2006). Moreover, $5 \mathrm{mg} / \mathrm{kg}$ but not $1 \mathrm{mg} / \mathrm{kg}$ yohimbine induces Fos expression in the lateral BNST (Myers et al, 2005). Finally, other studies in C57Bl/6J mice (Cain et al, 2004; Hefner et al, 2008), as well as a previous study from our lab (Davis et al, 2008) have found the $5 \mathrm{mg} / \mathrm{kg}$ dose effective at altering fear and anxietyrelated behaviors.

\section{Cocaine-CPP and Extinction}

The CPP and extinction design used here was described in detail previously (Davis et al, 2008). Briefly, the two chamber place preference apparatus consists of a box insert that slides into the open-field chamber (Med Associates; St Albans, VT). The paradigm consisted of a pre-test (day 1) and post-test (day 8) in which mice were given an intraperitoneal, (i.p.) saline injection and allowed unrestricted access to the contextually distinct mesh and bar-floor compartments. During conditioning, mice were given an i.p. saline injection and restricted to the mesh-floor compartment (days 2, 4, and 6) and an i.p. cocaine injection $(20 \mathrm{mg} /$ $\mathrm{kg}$ ) and restricted to the bar-floor compartment (days 3, 5, and 7). All sessions were for $15 \mathrm{~min}$.

The day following the post-test, extinction sessions began. Extinction sessions were the same as the preference session (access to both compartments) and were placed in one of the following four groups (time injection given before extinction session): SB-334867 (1 h)-vehicle (30 min), DMSO-vehicle (1 h)-yohimbine (30 min), DMSO-vehicle ( $1 \mathrm{~h})$-vehicle (30 min), and SB-334867 (1 h)-yohimbine (30 min). Immediately before each session, all mice were given an i.p. saline injection. Time spent in each compartment and the distance traveled was monitored throughout every session.

The data are presented as percent (\%) of pre-test preference in order to convey the magnitude of the change in preference more clearly and for statistical analysis purposes among many groups.

\section{Calcium Mobilization Assay}

Human Embryonic Kidney (HEK-EM4) cells expressing the $\mathrm{OX}_{1} \mathrm{R}$ were grown in Dulbecco's modified Eagle's medium (DMEM) containing $10 \%$ fetal bovine serum (FBS), $20 \mathrm{mM}$ HEPES ( $\mathrm{pH}$ 7.3), $2 \mathrm{mM}$ L-glutamine, $1 \times$ antibiotic/antimycotic, and $100 \mu \mathrm{g} / \mathrm{ml}$ Zeocin. HEK-293 cell lines coexpressing rat $\mathrm{mGluR}_{2}$ and G-protein-coupled inwardly rectifying potassium (GIRK) channels (for additional 
information, see Jin et al, 2010; Niswender et al, 2008) were grown in growth media containing 45\% DMEM, 45\% Ham's F12, 10\% FBS, $20 \mathrm{mM}$ HEPES ( $\mathrm{pH}$ 7.3), $1 \mathrm{mM}$ sodium pyruvate, $2 \mathrm{mM}$ L-glutamine, $1 \times$ antibiotic/antimycotic, $1 \times$ non-essential amino acids, $700 \mu \mathrm{g} / \mathrm{ml} \mathrm{G418} \mathrm{(Mediatech,}$ Inc., Herndon, VA), and $0.6 \mu \mathrm{g} / \mathrm{ml}$ puromycin dihydrochloride (Sigma-Aldrich, St Louis, MO) at $37^{\circ} \mathrm{C}$ in the presence of $5 \% \mathrm{CO}_{2}$. All cell culture reagents were purchased from Invitrogen (Carlsbad, CA). The cells were plated in noncoated (HEK-EM4) or poly-D-lysine-pretreated (HEK-293) 96-well black-walled, clear bottom plates (Corning Life Sciences, Lowell, MA) at $\sim 45000$ cells/well in growth media. Twenty-four hours later, $50 \mu \mathrm{l}$ of calcium assay buffer (Hanks' balanced salt solution (HBSS; Invitrogen, Carlsbad, CA), $20 \mathrm{mM}$ HEPES, $2.5 \mathrm{mM}$ probenecid (Sigma, St Louis, $\mathrm{MO}$ ), $\mathrm{pH}$ 7.4) containing $2 \mu \mathrm{M}$ Fluo-4 (Invitrogen) was added into each well and the cells were incubated for $1 \mathrm{~h}$ at room temperature in the dark. The cells were washed with assay buffer and then incubated in with either $80 \mu$ l (Figure $4 \mathrm{a}$ and c) or $40 \mu \mathrm{l}$ (Figure $4 \mathrm{~b}$ ) of assay buffer for $10 \mathrm{~min}$ at room temperature in the dark. Compounds were dissolved in the assay buffer, and the responses were recorded on a FLEXstation benchtop scanning fluorometer (Molecular Devices, Sunnyvale, CA) at room temperature, with the settings of $485 \mathrm{~nm}$ for excitation and $525 \mathrm{~nm}$ for emission. For Figures $6 \mathrm{a}$ and c, $20 \mu \mathrm{l}$ of a $5 \times$ compound was added at the 20-s time point and the fluorescence was monitored for a total of $240 \mathrm{~s}$. For Figure $6 \mathrm{~b}, 40 \mu \mathrm{l}$ of $2 \times$ SB-334867 was added at the $20 \mathrm{~s}$ time point, followed by addition of $5 \times$ compound at the $180 \mathrm{~s}$ time point and the fluorescence was monitored for a total of $240 \mathrm{~s}$. Maximal responses were observed with $\sim 1 \mu \mathrm{M}$ orexin $\mathrm{A}$ in orexin 1 receptor expressing cells and with $100 \mu \mathrm{M}$ ATP in mGluR $_{2}$-expressing cells. Thus, in each experiment the results are expressed as a percentage of the response obtained with $1 \mu \mathrm{M}$ orexin $\mathrm{A}$, or EC80 orexin A (300 nM) or $100 \mu \mathrm{M}$ ATP and are described as percentage of activation. Prism software (GraphPad Software Inc., San Diego, CA) was used to plot fluorescence intensities and to calculate the EC80 values.

\section{Ex Vivo BNST Electrophysiology}

Brain slice preparation. Brain slices from the dorsal anterolateral (dlBNST) were prepared as previously described (Egli et al, 2005; Weitlauf et al, 2004). Briefly, male C57Bl6/j mice (8-12 weeks old, Jackson Laboratories) were retrieved from the colony and allowed to rest in sound attenuating boxes for a minimum of $1 \mathrm{~h}$, after which they were decapitated under anesthesia (Isoflurane). The brains were quickly removed and placed in ice-cold artificial cerebro-spinal fluid (ACSF) (in mM: $124 \mathrm{NaCl}, 4.4 \mathrm{KCl}, 2$ $\mathrm{CaCl}_{2}, 1.2 \mathrm{MgSO}_{4}, 1 \mathrm{NaH}_{2} \mathrm{PO}_{4}, 10$ glucose, and $26 \mathrm{NaHCO}_{3}$ ). Slices of $300 \mu \mathrm{M}$ thickness were prepared using a vibratome (Leica). BNST slices containing anterior portions of BNST (bregma $0.26 \mathrm{~mm}$ to $0.02 \mathrm{~mm}$ ) (Franklin and Paxinos, 1997) were identified using the internal capsule, anterior commissure, fornix, and stria terminalis as landmarks. Following slicing, hemisected slices were placed in an interface chamber (field recordings) or a holding chamber prior to transfer to a submerged perfusion chamber (whole-cell recordings) and were continuously perfused with oxygenated $\left(95 \% \mathrm{O}_{2} / 5 \% \mathrm{CO}_{2}\right)$ and heated $\left(\sim 28^{\circ} \mathrm{C}\right) \mathrm{ACSF}$ at a rate of $2 \mathrm{ml} / \mathrm{min}$. Slices were allowed to equilibrate in normal ACSF for $1 \mathrm{~h}$ before experiments began. 1-3 hemisected slices were used per animal.

Extracellular field recordings. Low-resistance (2-3 M $\Omega$ ) extracellular electrodes were pulled with borosilicate glass on a Flaming-Brown Micropipette Puller (Sutter) and were filled with ACSF. Following dissection, slices were immediately placed in the interface chamber and allowed a minimum $60 \mathrm{~min}$ recovery period. Stimulating electrodes consisted of twisted, insulated nichrome bipolar wire. Stimulating electrodes were placed on the dorsal anterolateral BNST (dlBNST) border of the internal capsule approximately $200-500 \mu \mathrm{m}$ dorsal to the anterior commissure. To isolate excitatory transmission, all recordings were conducted in the presence of the $\mathrm{GABA}_{\mathrm{A}}$ receptor antagonist, picrotoxin $(25 \mu \mathrm{M})$. Field potential responses were evoked at a frequency of $0.05 \mathrm{~Hz}$ using a stimulus range of $5-15 \mathrm{~V}$ at a duration of $100-150 \mu \mathrm{s}$. Baseline responses (60\% of maximum evoked responses) were recorded for a minimum of 20 min before drug application. Experiments in which the N1 (Figure 1b) changed by $>20 \%$ were discarded.

Whole-cell patch-clamp recordings. Whole-cell recordings were performed as previously reported (Grueter and Winder, 2005; Kash and Winder, 2006). dBNST neurons were visualized and recorded via standard IR-DIC methods. Recording electrodes (4-6 M $\Omega$ ) were filled with the following for experiments examining excitatory transmission (in $\mathrm{mM}$ ): $117 \mathrm{Cs}$ gluconate, 20 HEPES, 0.4 EGTA, 5 TEA, 2 $\mathrm{MgCl}, 4 \mathrm{Na}_{2} \mathrm{ATP}, 0.3, \mathrm{Na}_{2} \mathrm{GTP}$ (pH 7.2-7.4, Osm. 270-290). EPSCs of 100-250 pA were recorded at a frequency of $0.1 \mathrm{~Hz}$ while voltage-clamped at $-70 \mathrm{mV}$ in the presence of the $\mathrm{GABA}_{\mathrm{A}}$ receptor antagonist, picrotoxin $(25 \mu \mathrm{M})$. After whole-cell configuration was achieved, cells were allowed to equilibrate a minimum of $5 \mathrm{~min}$ before baseline recordings were started. For experiments in which the effects of antagonists were determined, the antagonist was applied for at least $15 \mathrm{~min}$ before application of the agonist and remained on for the duration of the experiment. Access resistance, input resistance, and holding current were monitored continuously throughout the duration of the experiments. Recordings in which access resistance changed by more than $20 \%$ were excluded from analysis. Following an $8-10$ min baseline period, $2 \mu \mathrm{M}$ SB-334867, $1 \mu \mathrm{M}$ JNJ$10397049,100 \mathrm{nM}$ orexin A or $100 \mathrm{nM}$ reboxetine was bath applied for 35 (SB-334867 and JNJ-10397047) 10 (reboxetine) or 20 (orexin A) min. Baseline values were calculated as an average of $3 \mathrm{~min}$ directly before agonist application. Recorded data was analyzed via Clampfit 10.2 (Molecular Devices). Both the \% coefficient of variation (CV) and paired-pulse ratio (PPR) were examined to assess alterations in presynaptic release probability. Paired pulses with a $70 \mathrm{~ms}$ interstimulus interval were given every $20 \mathrm{~s}$. The PPR was the ratio of averaged amplitude of the second EPSC (EPSC2) to that of the first EPSC (EPSC1).

\section{Drugs}

The following drugs were used for experiments: cocaine hydrochloride (National Institute on Drug Abuse, Bethesda, MD), SB-334867, 1-(2-methylbenzoxazol-6-yl)-3-[1,5] naphthyridin-4-yl urea hydrochloride; Tocris, Ellisville, 
a
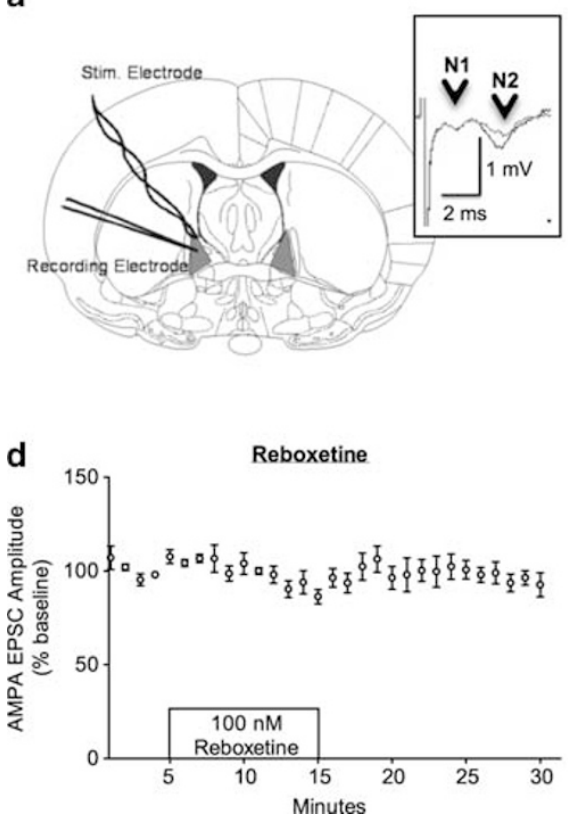
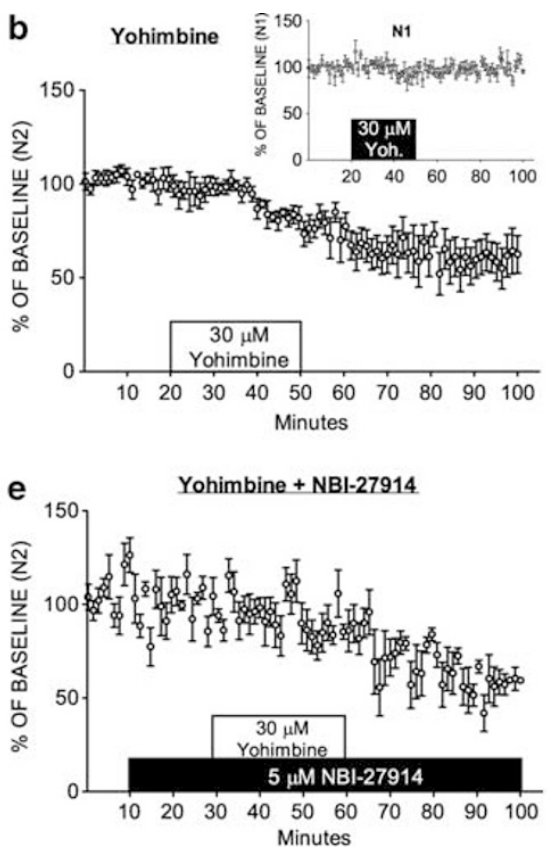

C
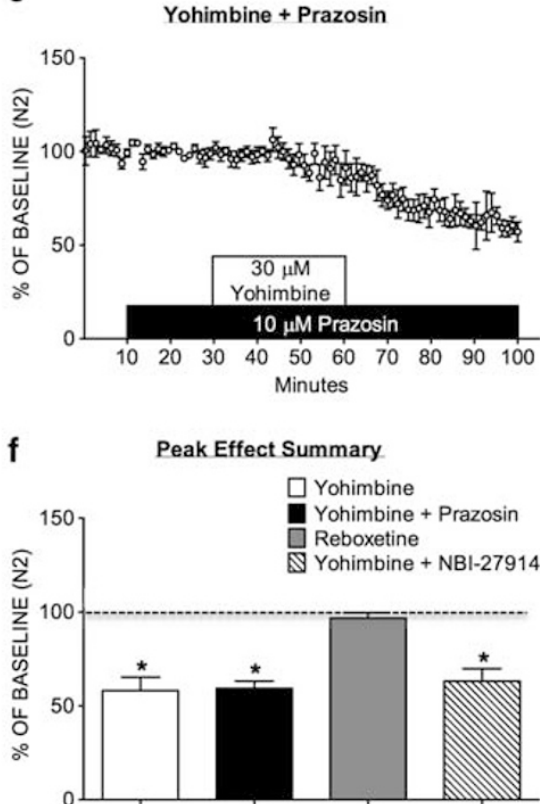

Figure I Norepinephrine and corticotrophin releasing factor (CRF) receptor I (CRFR $)$ antagonists do not block yohimbine-induced depression of excitatory transmission in the dorsal anterolateral bed nucleus of the stria terminalis (dIBNST). Extracellular field potential and whole-cell patch-clamp recordings of excitatory transmission in the dIBNST: (a) left, diagram of coronal section containing the dIBNST and demonstrating placement of stimulating and recording electrodes during electrophysiological recordings; right, a representative extracellular field potential recording trace depicting the TTXsensitive NI downward deflection and CNQX-sensitive N2 downward deflection. (b) $30 \mu \mathrm{M}$ yohimbine inset: corresponding NI; six slices recorded from five mice. (c) $30 \mu \mathrm{M}$ yohimbine in the presence of $10 \mu \mathrm{M}$ prazosin; six slices recorded from four mice. (d) I00 nM Reboxetine; six slices recorded from four mice. (e) $30 \mu \mathrm{M}$ yohimbine in the presence of $5 \mu \mathrm{M}$ NBI-279I4; six slices recorded from five mice. (f) Summary of 86-90 min for yohimbine, prazosin + yohimbine, Reboxetine, NBI-279/4 + yohimbine. Data are represented as mean \pm SEM, $* p<0.05, n=5-6$ slices per group.

Missouri), NBI-27914 (Sigma-Aldrich, St Louis, MO), yohimbine $\mathrm{HCl}$ (Sigma-Aldrich), methoxamine hydrochloride (Sigma-Aldrich), prazosin (Tocris), ATP (Sigma-Aldrich), carbachol (Sigma-Aldrich), orexin A (Ascent, Scientific, Princeton, NJ), JNJ-10397047 and 2-\{4-[5methyl-2-(2H-1,2,3-triazol-2-yl)benzoyl]-1,4-diazepan-1-yl\}quinazoline (MTBDQ; C Lindsley, Vanderbilt University), reboxetine (Tocris) and picrotoxin (Sigma-Aldrich). For the electrophysiology experiments, drugs were bath-applied at final concentrations, which are noted in the experimental design. DMSO is the solvent used for picrotoxin, NBI-27914, JNJ-10397047, prazosin, MTBDQ, orexin A, and SB-334867 in which the maximum final concentration of DMSO was $0.02 \%$ by volume. Methoxamine and yohimbine were dissolved in $\mathrm{ddH}_{2} \mathrm{O}$. Reboxetine was dissolved in $0.9 \%$ saline.

\section{Statistical Analysis}

When determining whether a drug had a significant effect, or mice displayed a significant difference between their expressed pre- and post-test preference for the cocainepaired chamber, a paired Student's $t$-test was used to compare the baseline value (or pre-test preference) to the drug effect value (or post-test preference). Unpaired Student's $t$-test was used for determining effects between two separate experimental conditions (eg, post-test preference for the cocaine paired chamber between $\alpha_{2 \mathrm{~A}}$-AR-WT and $\mathrm{KO}$ mice). When comparing effects across more than two drug application experiments, a one-way analysis of variance (ANOVA) was used. For extinction of cocaine-CPP experiments, a two-way ANOVA repeated measures (RM) was used. Student Newman Keuls or Holmes-Sidak multiple comparison post hoc test were used; if equal variance criteria were not met, the Games-Howell post hoc test was used.

\section{RESULTS}

\section{Norepinephrine and Corticotrophin Releasing Factor (CRF) Receptor $1\left(\right.$ CRFR $\left._{1}\right)$ Antagonists Do Not Block Yohimbine-induced Depression of Excitatory Transmission in the dlBNST}

A representative depiction of the location for all electrophysiological recordings of our stimulating and recording electrodes in slices containing the dlBNST is presented in Figure 1a (left) and a representative extracellular field potential recording trace depicting the TTX-sensitive $\mathrm{N} 1$ (used to monitor slice health) downward deflection and CNQX-sensitive N2 downward deflection (Figure 1a; right, boxed inset). Extracellular field potential recordings from the dlBNST revealed that a $30 \mathrm{~min}$ bath application of $30 \mu \mathrm{M}$ yohimbine resulted in a depression of excitatory transmission $\left(58.3 \pm 6.9 \%\right.$ of baseline in $86-90 \mathrm{~min}, t_{5}=4.507$, $p=0.004, n=6$ slices from five mice, Figure $1 \mathrm{~b})$, similar to our previous report (Davis et al, 2008) and the $\mathrm{N} 1$ was unaffected in these recordings (inset; Figure 1b). We previously demonstrated that (a) this effect is not fully mimicked by the more selective $\alpha_{2}$-AR antagonist 
atipamezole, and was not disrupted in slices obtained from $\alpha_{2 \mathrm{~A}}$-AR KO mice (Davis et al, 2008). As multiple actions of norepinephrine are disrupted in the BNST of these mice (Egli et al, 2005; McElligott et al, 2010), these data suggest that the actions of yohimbine on excitatory transmission are not likely mediated by $\alpha_{2}$-AR binding, or other norepinephrine dependent processes. It has recently been reported that the $\alpha_{1}-\mathrm{AR}$ antagonist prazosin can block yohimbineinduced drug-seeking behavior (Le et al, 2011). Thus, to further explore this issue, we assessed the ability of prazosin to block the depressant effects of yohimbine on excitatory transmission in the BNST. A $30 \mathrm{~min}$ application of $30 \mu \mathrm{M}$ yohimbine in the presence of $10 \mu \mathrm{M}$ prazosin depressed excitatory transmission $(59.3 \pm 3.9 \%$ of baseline in $86-90$ min, $t_{5}=11.52,{ }^{*} p<0.001, n=6$ slices from four mice, Figure 1c) in a manner that was not significantly different from that elicited by yohimbine alone (yohimbine in the presence of $10 \mu \mathrm{M}$ prazosin compared with $30 \mu \mathrm{M}$ yohimbine: $F_{3,18}=0.1, p=$ n.s., Figure 1f). Finally, we assessed whether the norepinephrine transporter blocker reboxetine (100 nM), by elevating norepinephrine levels, could mimic the actions of yohimbine. Thus, if the available pool of synaptic norepinephrine in a deafferented slice is dynamic enough to be regulated by autoreceptors and produce the depressant effect elicited by yohimbine on excitatory transmission, we reasoned that reboxetine should mimic this effect. Utilizing whole-cell patch clamp recordings, a $10 \mathrm{~min}$ application of $100 \mathrm{nM}$ reboxetine had no effect (96.8\% of baseline in $25-30 \mathrm{~min}, t_{5}=0.8 ; p=$ n.s., $n=6$ slices from four mice, Figure 1d) on excitatory transmission in our experiments, as would be predicted in a deafferented slice where noradrenergic inputs are severed. These results suggest that modulation of extracellular norepinephrine levels is unlikely to contribute to the depressant effects of yohimbine on excitatory transmission in the dlBNST.

Given the anxiogenic effect of yohimbine and the presence of CRF neurons and terminals in the BNST (Champagne et al, 1998), we next assessed if $\mathrm{CRFR}_{1}$ may be the target for the depressant effects of yohimbine on excitatory transmission. A $30 \mathrm{~min}$ application of yohimbine in the presence of the $\mathrm{CRFR}_{1}$ antagonist, NBI-27914, elicited a significant depression on excitatory transmission $\left(63.2 \pm 6.7 \%\right.$ of baseline, $t_{5}=6.5,{ }^{*} p=0.0013, n=6$ slices from five mice, Figure $1 \mathrm{e}$ and $\mathrm{f}$ ), demonstrating that $\mathrm{CRFR}_{1}$ does not mediate the yohimbine-induced depression of excitatory transmission in the BNST.

\section{Orexin Receptor (OxR) Antagonists Block Yohimbine- induced Depression of Excitatory Transmission in the dlBNST}

Orexin A has been implicated in anxiety and reward-related behaviors (Buffalari and See, 2010; Dayas et al, 2008; Espana et al, 2010; Harris et al, 2005; Johnson et al, 2010; Lawrence et al, 2006; Richards et al, 2008), and the BNST receives dense orexinergic innervation (Baldo et al, 2003). To test the role of orexin signaling in the effects of yohimbine, we assessed the ability of OxR antagonists to block its actions. When applied alone, the $\mathrm{OX}_{1} \mathrm{R}$ antagonist, SB-334867 $(5 \mu \mathrm{M})$, had no significant effect on excitatory transmission, even with extensive pretreatment $(91.6 \pm 3.8 \%$ of baseline in 86-90 $\mathrm{min}, t_{6}=1.03, p=$ n.s., $n=7$ slices from four mice;
Figure 2a). However, pretreatment with $5 \mu \mathrm{M}$ SB-334867 prevented yohimbine-induced depression of excitatory transmission $(101.6 \pm 2.6 \%$ of baseline in $86-90 \mathrm{~min}$, $t_{5}=0.4, p=$ n.s, $n=6$ from four mice, Figure $2 \mathrm{~b}$ ). Similarly, a $30 \mathrm{~min}$ application of a novel dual $\mathrm{OX}_{1} \mathrm{R}$ and $\mathrm{OX}_{2} \mathrm{R}$ antagonist, MTBDQ $(1 \mu \mathrm{M})$, also had no effect on excitatory transmission $(98.8 \pm 2.6 \% \%$ of baseline in $86-90 \mathrm{~min}$, $t_{5}=1.2, p=$ n.s., $n=6$ slices from three mice, Figure $2 \mathrm{~d}$ ). Similar to what was observed with the $\mathrm{OX}_{1} \mathrm{R}$, pretreatment with $1 \mu \mathrm{M}$ MTBDQ prevented yohimbine-induced depression of excitatory transmission $(101.1 \pm 28.3 \%$ of baseline in 86-90 $\mathrm{min}, t_{6}=0.1, p=$ n.s., $n=7$ slices from five mice, Figure $2 \mathrm{e})$. These results are summarized as peak drug effects at $86-90 \min \left(\mathrm{F}_{4,26}=9.9\right.$; ${ }^{\star} p<0.05$ for the yohimbine group compared with all other groups; Figure $2 \mathrm{c}$ ).

\section{$\mathrm{OX}_{1} \mathrm{R}$-Dependent orexin A-Induced Depression of AMPA EPSCs in the dIBNST}

Our findings suggest that an OxR agonist may mimic the effects of yohimbine on excitatory transmission in the dlBNST. Two recent studies reported that in the hippocampus and ventrolateral periaqueductal gray (vlPAG), orexin A elicited a depression of excitatory transmission in young animals (Ho et al, 2011; Selbach et al, 2010). We thus investigated the effects of exogenous orexin A on excitatory transmission in the dlBNST. Consistent with our hypothesis, in the majority of cells recorded (13 of 16 cells recorded from 10 mice), a 20 min application of $100 \mathrm{nM}$ orexin A resulted in a slowly developing and significant reduction of $\alpha$-amino-3-hydroxy-5-methyl-4-isoxazolepropionic acid (AMPA) EPSC amplitude $(41.9 \pm 7.0 \%$ decrease from baseline; $t_{12}=6.3$, ${ }^{*} p<0.01, n=13$, Figure $3 \mathrm{a}$ ) and EPSC area $\left(35.2 \pm 6.2 \%\right.$ decrease from baseline: $t_{12}=6.6$, ${ }^{*} p<0.05$, Figure $3 \mathrm{a}$ inset), with no significant changes to EPSC kinetics (rise: $t_{12}=0.4, p=$ n.s.; decay: $t_{12}=0.2$, $p=$ n.s., Figure $3 a$ inset). In the remaining cells ( 3 of 16 cells recorded), $20 \mathrm{~min}$ application of $100 \mathrm{nM}$ orexin A had no significant effect on EPSC amplitude, area, or kinetics (data not shown). PPR and CV analysis was undertaken to investigate changes in presynaptic release probability. Interestingly, PPR $\left(t_{12}=3.2,{ }^{\star} p<0.05\right.$, Figure $\left.3 \mathrm{~b}\right)$ and $\mathrm{CV}$ $\left(t_{12}=3.4,{ }^{\star} p<0.05\right.$, Figure $\left.3 c\right)$ were increased compared with baseline, consistent with an orexin A-mediated decrease in presynaptic glutamate release probability.

As previous studies suggest the BNST has a moderate to high density of $\mathrm{OX}_{1} \mathrm{R}$ and $\mathrm{OX}_{2} \mathrm{R}$ mRNA and protein expression (Hervieu et al, 2001; Marcus et al, 2001), we next investigated whether the orexin A depression of excitatory transmission was $\mathrm{OX}_{1} \mathrm{R}$ - or $\mathrm{OX}_{2} \mathrm{R}$-dependent. We found that pretreatment with the $\mathrm{OX}_{1} \mathrm{R}$ antagonist, SB-334867 $(2 \mu \mathrm{M})$ attenuated the orexin A mediated depression with no significant changes in AMPA EPSC amplitude $(6.6 \pm 9.4 \%$ decrease from baseline, $t_{4}=0.2 ; p=$ n.s., $n=5$ slices from five mice, Figure $3 \mathrm{~d}$ ). Consistent with these findings, no changes were observed in $\operatorname{PPR}\left(t_{4}=0.1 ; p=\right.$ n.s., Figure $\left.3 \mathrm{e}\right)$ and $\mathrm{CV}\left(t_{4}=0.1 ; p=\right.$ n.s., Figure $\left.3 \mathrm{f}\right)$. In contrast, pretreatment with the $\mathrm{OX}_{2} \mathrm{R}$ antagonist, JNJ-10397047 (1 $\left.\mu \mathrm{M}\right)$ did not prevent a significant reduction in EPSC amplitude by orexin A $\left(47.8 \pm 4.9 \%\right.$ decrease from baseline, $t_{4}=6.7,{ }^{\star} p<0.05$, $n=5$ slices from four mice, Figure $3 \mathrm{~g})$. Moreover, an increase in both PPR $\left(t_{4}=7.4,{ }^{\star} p<0.05\right.$, Figure $\left.3 \mathrm{~h}\right)$ and $\mathrm{CV}\left(t_{4}=2.9\right.$, 

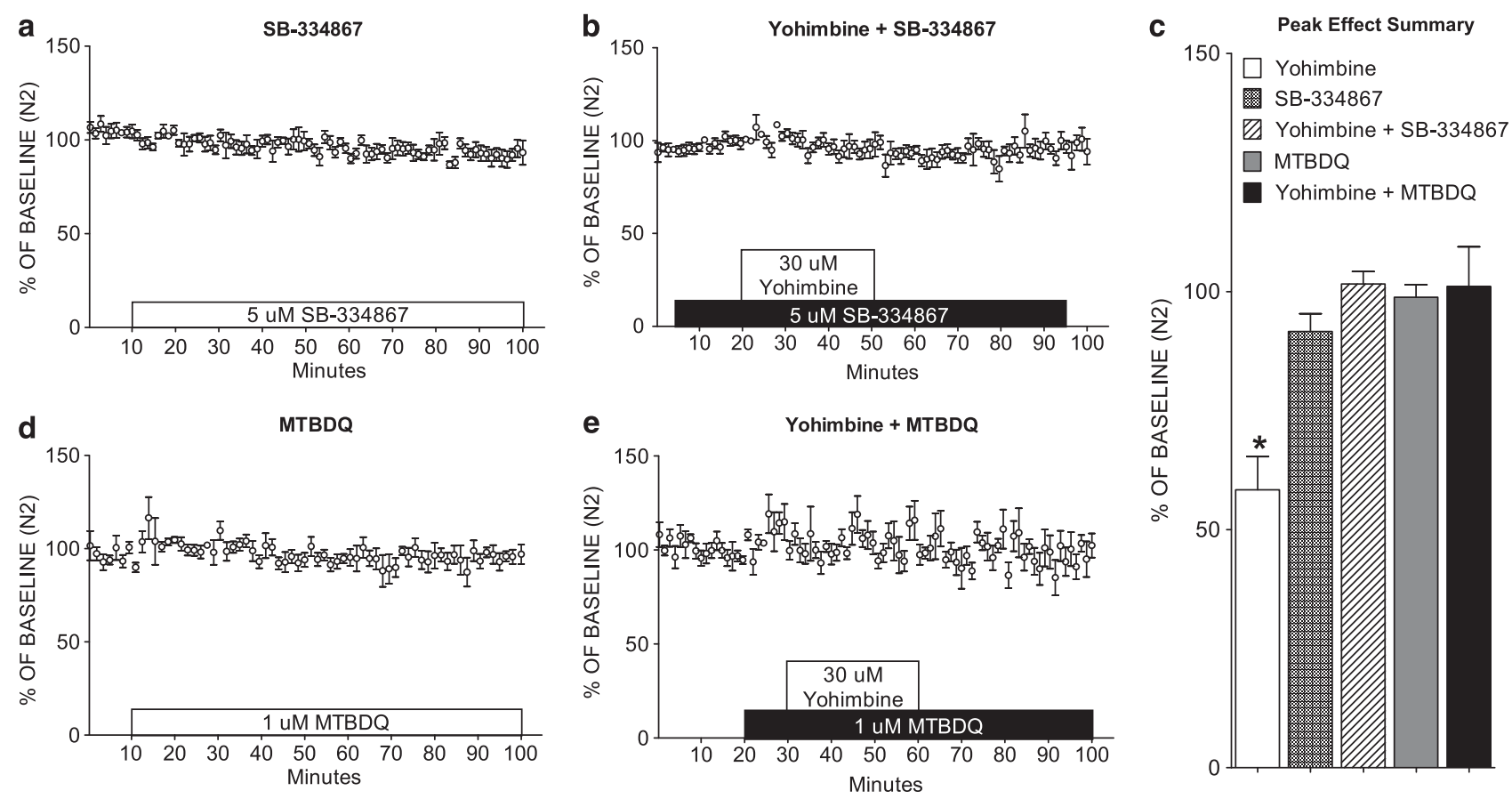

Figure 2 Orexin receptor $(\mathrm{O} x \mathrm{R})$ antagonists block yohimbine-induced depression of excitatory transmission in the dorsal anterolateral bed nucleus of the stria terminalis (dIBNST). Extracellular field potential recordings of excitatory transmission in the dIBNST. (a) $5 \mu$ M SB-334867; seven slices recorded from four mice. (b) $30 \mu \mathrm{M}$ yohimbine in the presence of $5 \mu \mathrm{M}$ SB-334867; six slices recorded from four mice. (c) Summary of 86-90 min for yohimbine, 2-\{4-[5-methyl-2-(2H-I,2,3-triazol-2-yl)benzoyl]-I,4-diazepan-I-yl\}quinazoline (MTBDQ), MTBDQ + yohimbine, SB-334867, SB-334867+yohimbine. (d) I $\mu$ M MTBDQ; six slices recorded from three mice. (e) $30 \mu \mathrm{M}$ yohimbine in the presence of I $\mu \mathrm{M} M T B D Q$; seven slices recorded from five mice. Data are represented as mean \pm SEM, $* p>0.05, n=6-7$ slices per group.

${ }^{*} p<0.05$, Figure 3i) were observed, indicating that application of orexin $\mathrm{A}$ in the presence of an $\mathrm{OX}_{2} \mathrm{R}$ antagonist did not effect presynaptic release probability. These results strongly suggest that orexin $\mathrm{A}$ acts at the $\mathrm{OX}_{1} \mathrm{R}$ to depress excitatory transmission in dlBNST.

\section{Yohimbine Does Not Directly Activate $\mathrm{OX}_{1} \mathrm{R}$ Signaling}

Our results demonstrate both an $\mathrm{OX}_{1} \mathrm{R}$ and novel dual $\mathrm{OX}_{1} \mathrm{R} / \mathrm{OX}_{2} \mathrm{R}$ antagonist attenuate yohimbine-induced depression of excitatory transmission (Figure 2), and these depressant effects of yohimbine on excitatory transmission are mimicked by orexin $\mathrm{A}$ in an $\mathrm{OX}_{1} \mathrm{R}$-dependent manner (Figure 3), indicating that yohimbine depresses excitatory transmission in dlBNST by recruiting OxR signaling. This could be accomplished either via direct action of yohimbine on Ox1R, or via regulation of orexin release to activate the receptor. To address the former issue, we investigated the ability of yohimbine to act as a direct ligand and activate the $\mathrm{OX}_{1} \mathrm{R}$ utilizing a stable $\mathrm{OX}_{1} \mathrm{R}$ cell line and calcium mobilization assay. Increasing concentrations of orexin $\mathrm{A}$, yohimbine, and ATP were applied to HEK-EM4 cells stably expressing the $\mathrm{OX}_{1} \mathrm{R}$ and calcium mobilization was measured. The $\mathrm{EC}_{50}$ for orexin $\mathrm{A}$ was $\sim 72 \pm 6 \mathrm{nM}$, the $\mathrm{EC}_{50}$ for yohimbine $>1 \mathrm{mM}$, and the $\mathrm{EC}_{50}$ for ATP was $709 \pm 40 \mathrm{nM}$ in HEK-EM4 cells expressing the $\mathrm{OX}_{1} \mathrm{R}$ (Figure 4a). In the HEK-EM4 $\mathrm{OX}_{1} \mathrm{R}$ expressing cells the $\mathrm{OX}_{1} \mathrm{R}$ antagonist SB-334867 fully inhibited the effects of an $\mathrm{EC}_{80}$ concentration of orexin $\mathrm{A}\left(\mathrm{IC}_{50} \sim 109 \pm 3 \mathrm{nM}\right)$, whereas it had no effect on the signal produced by $1 \mathrm{mM}$ yohimbine
$\left(\mathrm{IC}_{50}>1 \mathrm{mM}\right.$; Figure $\left.4 \mathrm{~b}\right)$. To determine whether the $\mathrm{mM}$ yohimbine concentrations required to observe a calcium mobilization response were related to $\mathrm{OX}_{1} \mathrm{R}$ expression, carbachol, yohimbine, and ATP were applied to HEK 293 cells co-expressing $\mathrm{mGluR}_{2}$ and GIRKs. The $\mathrm{EC}_{50}$ for carbachol was $>30 \mu \mathrm{M}, \mathrm{EC}_{50}$ for yohimbine $>1 \mathrm{mM}$, and the $\mathrm{EC}_{50}$ for ATP was $420 \pm 83 \mathrm{nM}$ (Figure 4c). All experiments were performed in triplicate. These results suggest that yohimbine does not directly recruit $\mathrm{OX}_{1} \mathrm{R}$ signaling and more likely acts by indirectly promoting orexin release to influence orexin receptor signaling.

\section{Yohimbine-Induced Depression of Excitatory Transmission in the dlBNST is Absent in Prepro-orexin Knockout Mice}

If yohimbine acts on dlBNST excitatory transmission via promoting the release of orexin, it would be predicted that this effect would be absent in dlBNST slices prepared from prepro-orexin knockout (Ox-KO) mice. Thus, we assessed the ability of yohimbine to depress excitatory transmission in the dlBNST in Ox-KO mice (Willie et al, 2003). Yohimbine $(30 \mu \mathrm{M}, 30 \mathrm{~min})$ had no significant effect on excitatory transmission in the dlBNST $(94.9 \pm 7.2 \%$ of baseline in $86-90$ $\min , t_{4}=0.5, p=$ n.s., $n=5$ slices from three mice, Figure 5) in slices from Ox-KO mice; consistent with the idea that yohimbine acts via promoting orexin release in the dlBNST to depress glutamatergic transmission. 

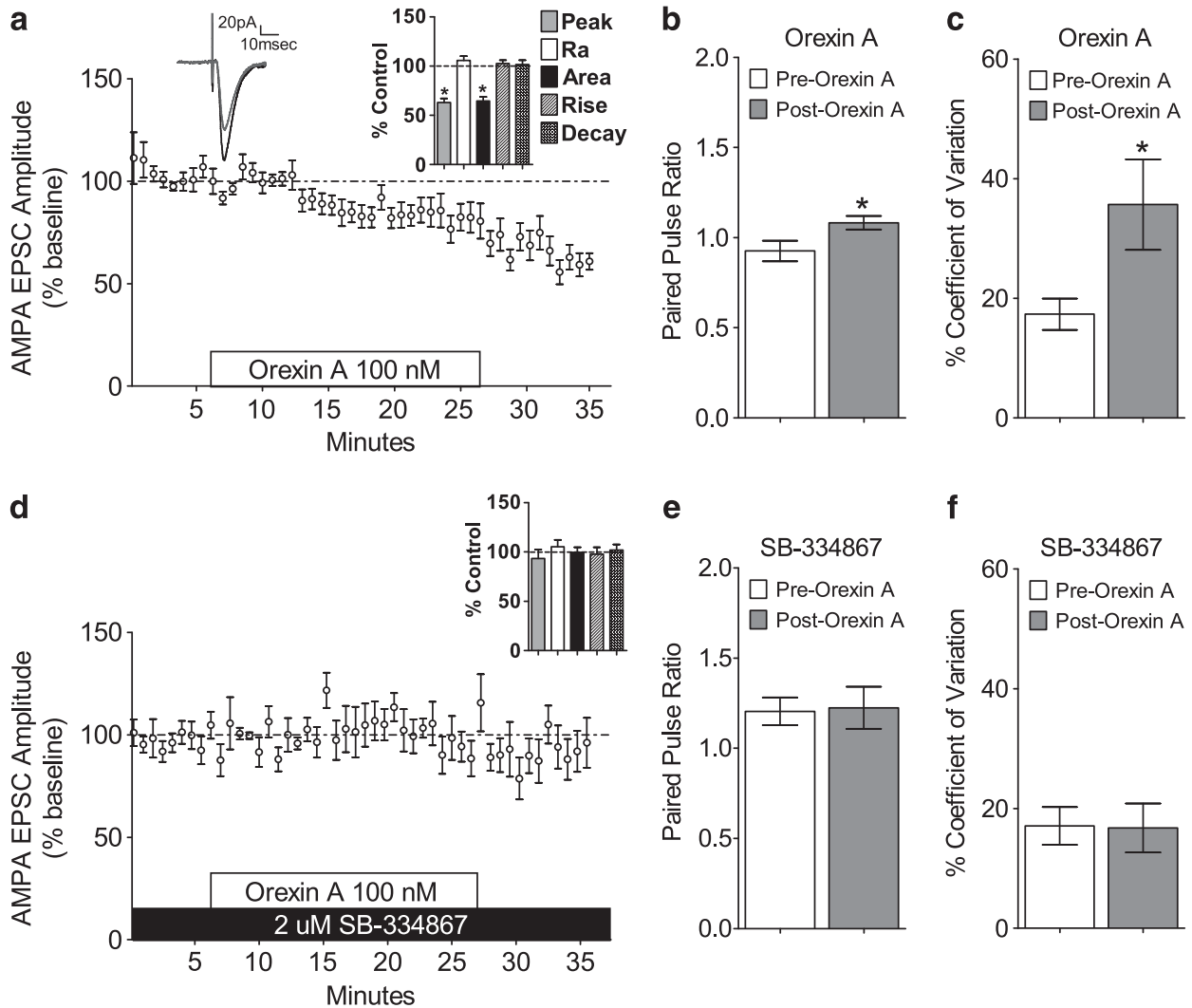

f
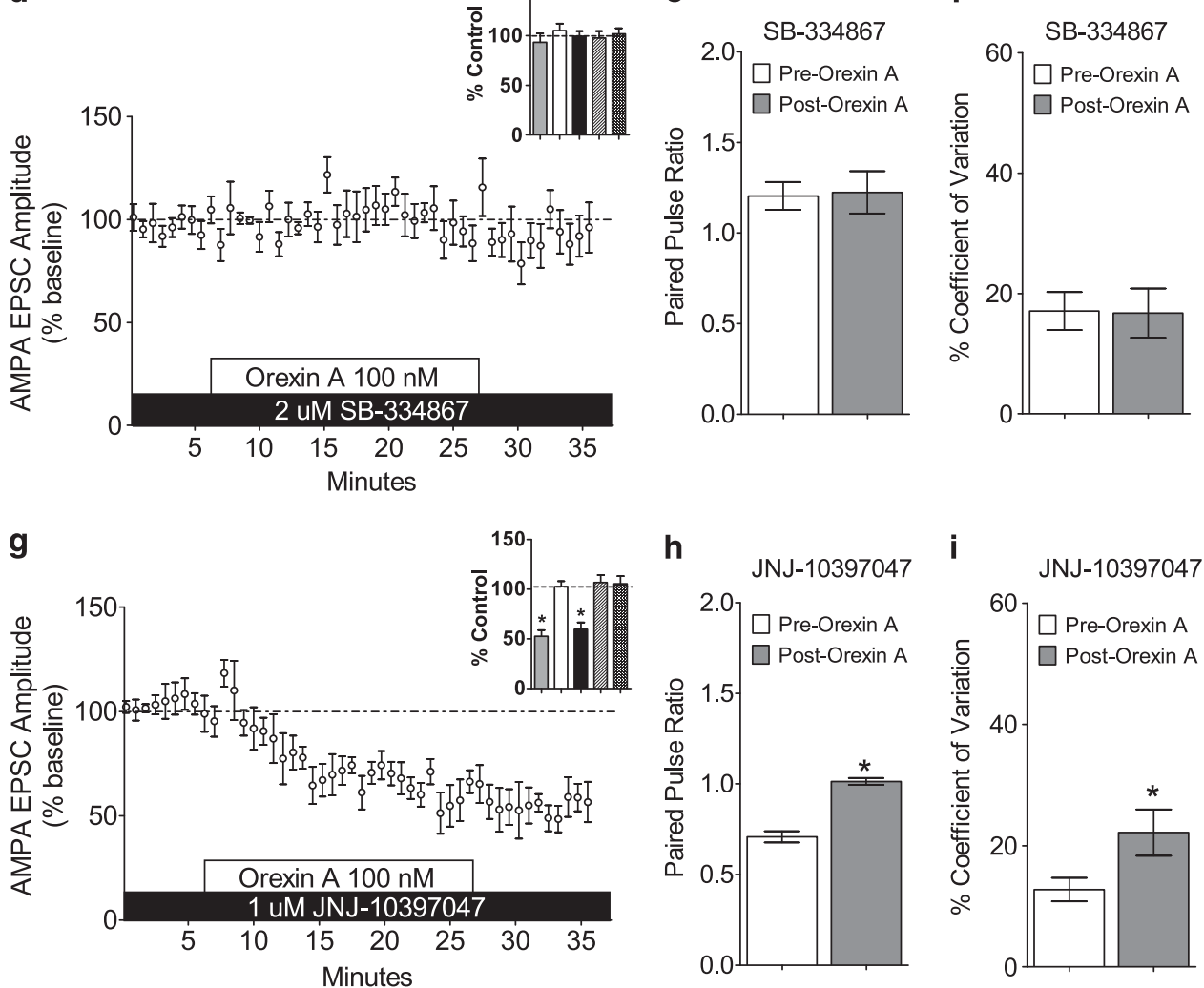

Figure 3 OX,R-dependent orexin A-induced depression of $\alpha$-amino-3-hydroxy-5-methyl-4-isoxazolepropionic acid (AMPA) EPSCs in the dIBNST. Whole-cell patchclamp recordings of AMPA EPSCs in the dIBNST. (a) Time course showing the effect of I00 nM orexin A on the peak amplitude of AMPA EPSCs in 13 out of 16 cells recorded from 10 mice; inset: representative trace from whole-cell recording (baseline: black line; post-orexin A: blue line); boxed inset: Summary of cell parameters monitored throughout recordings: amplitude, access resistance (Ra), area, rise time, and decay time of EPSCs. * indicated significant difference from baseline. (b) PPR of pre-orexin A and post-orexin A application. (c) \% coefficient of variation (CV) in pre-orexin A and postorexin A events. (d) Time course showing the effect of $100 \mathrm{nM}$ orexin A in the presence of $2 \mu \mathrm{M}$ of the OX $\mathrm{R}$ (orexin receptor I) antagonist, SB-334867, on the peak amplitude of AMPA EPSCs in 5 out of 5 cells recorded from five mice. Boxed Inset: Summary of cell parameters monitored throughout recordings: amplitude, access resistance $(\mathrm{Ra})$, area, rise time, and decay time of EPSCs * indicated significant difference from baseline. (e) In the presence of SB-334867, PPR of pre-orexin A and post-orexin A application. (f) In the presence of SB-334867, \% CV of pre-orexin A and post-orexin A events. (g) Time course showing the effect of $100 \mathrm{nM}$ orexin $\mathrm{A}$ in the presence of I $\mu \mathrm{M}$ of the OX ${ }_{2} \mathrm{R}$ antagonist, JNJ-10397047, on the peak amplitude of AMPA EPSCs in 5 out of 5 cells recorded from four mice. Boxed Inset: Summary of cell parameters monitored throughout recordings: amplitude, access resistance (Ra), area, rise time, and decay time of EPSCs * indicated significant difference from baseline. (h) In the presence of JNJ- I0397047, PPR of pre-orexin A and post-orexin A application. (i) In the presence of JNJ- I0397047, \% CV of pre-orexin A and post-orexin A events. The color reproduction of the figure is available at the Neuropsychopharmacology journal online.

\section{$\alpha_{1}$-AR-Induced Depression of Excitatory Transmission in the dlBNST is Not Blocked by an $\mathrm{OX}_{1} \mathrm{R}$ Antagonist}

As shown above, orexin $\mathrm{A}$, acting at the $\mathrm{OX}_{1} \mathrm{R}$, depresses excitatory transmission in the dlBNST. Similarly, previous work in our lab has demonstrated that several other
Gq-linked receptors (eg, $\alpha_{1}$-AR, mGluR1, mGluR5) cause a depression of excitatory transmission in the dlBNST (Gosnell et al, 2011; Grueter et al, 2006; McElligott et al, 2010; McElligott and Winder, 2008, 2009). Although the $\alpha_{1}$-AR antagonist prazosin did not block yohimbine-induced depression of excitatory transmission (see above), to further 

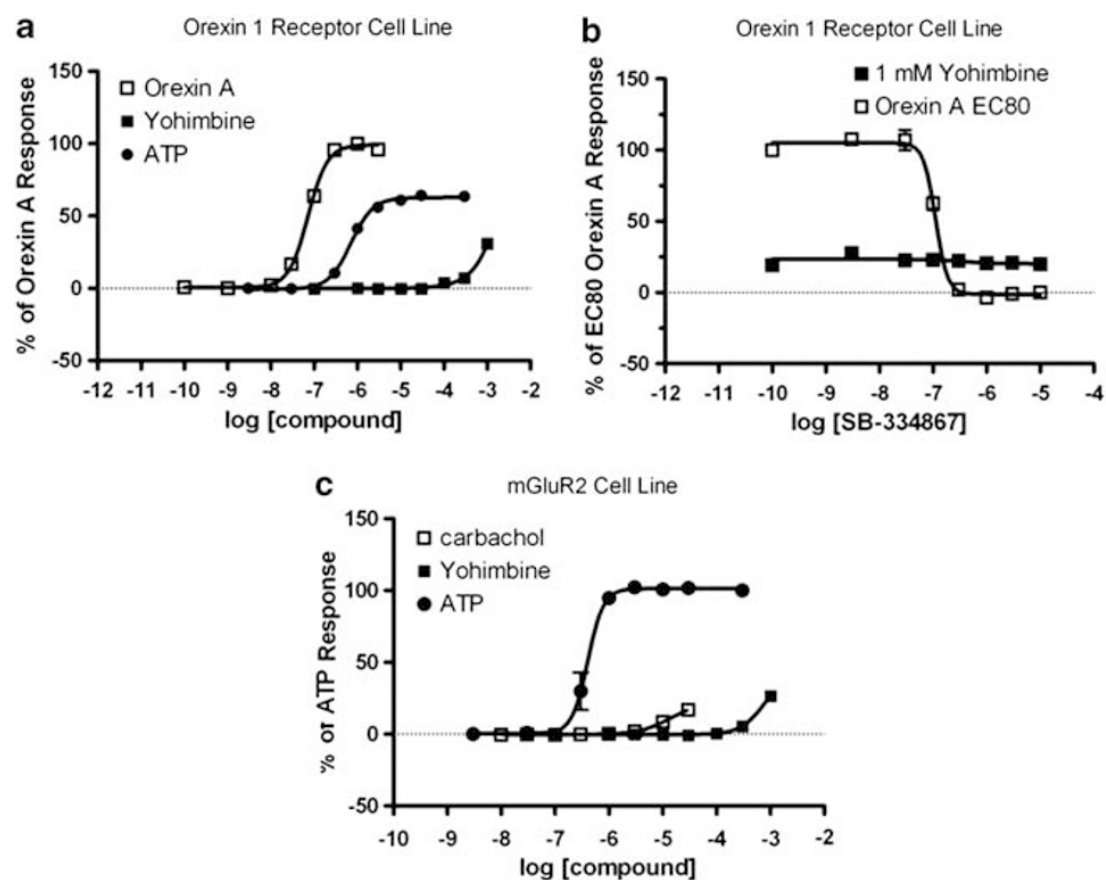

Figure 4 Yohimbine does not directly activate OX, R signaling. Concentration-response curves (CRCs) of (a) orexin A, yohimbine, and ATP in HEK-EM4 cells expressing orexin I receptor (OX,R-Cs). (b) Effects of I mM yohimbine or EC80 orexin A in SB-334867 pre-treated OX,R-Cs. (c) Carbachol, yohimbine, and ATP in HEK 293 cell co-expressing rat mGluR 2 and G-protein-coupled inwardly rectifying potassium (GIRK) channels (mGluR 2 Cell Line). All data are expressed as the mean of a minimum of three independent experiments performed in triplicate. Data are represented as mean \pm SEM.

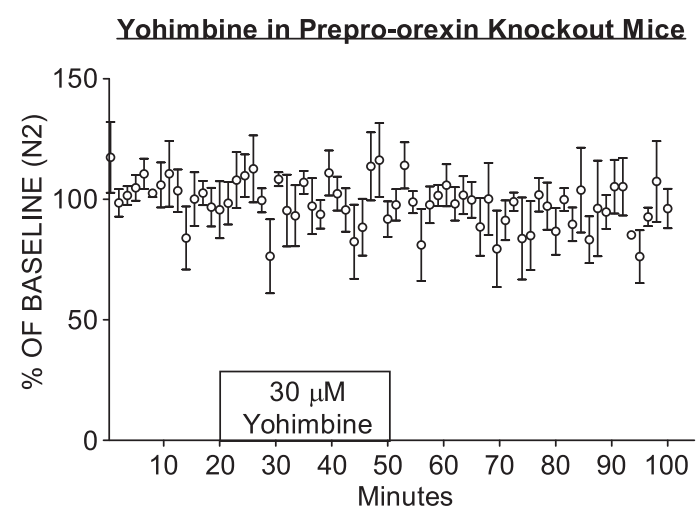

Figure 5 Yohimbine-induced depression of excitatory transmission in the dlbnst is absent in prepro-orexin (ox) knockout mice. Extracellular field potential recordings of excitatory transmission in the dIBNST of preproorexin knockout $(\mathrm{Ox}-\mathrm{KO})$ mice. $30 \mu \mathrm{M}$ yohimbine. Data are represented as mean $\pm \mathrm{SEM}, p=$ n.s., $n=5$ slices from three mice.

address possible activation of common downstream effectors, we investigated if an $\mathrm{OX}_{1} \mathrm{R}$ antagonist could block methoxamine (a Gq-linked $\alpha_{1}$-AR)-induced depression in the dlBNST. A $30 \mathrm{~min}$ application of methoxamine $(100 \mu \mathrm{M})$ elicited a significant depression in excitatory transmission $\left(66.1 \pm 3.5 \%\right.$ of baseline in $86-90 \mathrm{~min}, t_{5}=6.2,{ }^{*} p<0.05$, $n=6$ slices from four mice, Figure $6 \mathrm{a}$ ). A $30 \mathrm{~min}$ application of $100 \mu \mathrm{M}$ methoxamine in the presence of $5 \mu \mathrm{M}$ SB-334867 still elicited a significant depression of excitatory transmission $\left(71.7 \pm 4.3 \%\right.$ of baseline in $86-90 \mathrm{~min}, t_{6}=7.5,{ }^{\star} p<0.05$, $n=7$ slices from four mice, Figure $6 \mathrm{~b}$ ) that was not significantly different from the depression elicited by $100 \mu \mathrm{M}$ methoxamine alone $\left(\mathrm{F}_{2,17}=10.9,{ }^{*} p<0.05\right.$ for methoxamine compared to SB-334867, ${ }^{*} p<0.05$ for SB$334867+$ methoxamine compared with SB-334867, $p=$ n.s. for methoxamine compared with methoxamine + SB-334867; Figure $6 \mathrm{c}$ ). Taken together, these results demonstrate that the $\alpha_{1}$-AR mediated depression of excitatory transmission is independent from the yohimbine-inducible and $\mathrm{OX}_{1} \mathrm{R}$ dependent depression of excitatory transmission observed in the dlBNST.

\section{$\mathrm{OX}_{1} \mathrm{R}$ Antagonist, SB-334867, Blocks Yohimbine- induced Impairment of Extinction of Cocaine-CPP in $\alpha 2_{\mathrm{A}}-\mathrm{AR}$ Wild-Type and KnockOut Mice}

Recent studies have demonstrated that an $\mathrm{OX}_{1} \mathrm{R}$ antagonist, SB-334867, can attenuate yohimbine-induced reinstatement of drug-seeking behavior (Richards et al, 2008; Zhou et al, 2011). However, the role of $\mathrm{OX}_{1} \mathrm{Rs}$ in the extinction of stress-induced increases in cocaine-seeking behavior is unknown. Although our understanding of the neural mechanisms and substrates critical to reinstatement of drug-seeking behavior have increased substantially in recent years, the role of a potentially therapeutically viable method to help achieve and maintain abstinence, extinction training, has lagged considerably (Millan et al, 2011; Myers and Carlezon, 2010). To determine if systemic administration of an $\mathrm{OX}_{1} \mathrm{R}$ antagonist (SB-334867) can attenuate yohimbine-induced impairment of extinction of cocaineCPP, $\alpha_{2 \mathrm{~A}}-\mathrm{AR}$ wild-type $\left(\alpha_{2 \mathrm{~A}}-\mathrm{AR}-\mathrm{WT}\right)$ and knockout $\left(\alpha_{2 \mathrm{~A}}-\mathrm{AR}-\mathrm{KO}\right)$ mice were tested using a previously employed cocaine-CPP and extinction paradigm (Davis et al, 2008). $\alpha_{2 \mathrm{~A}}-\mathrm{AR}-\mathrm{WT}$ and KO littermate mice display cocaine-CPP when tested during a $15-$ min post-test session (post-test preference expressed compared with pre-test 

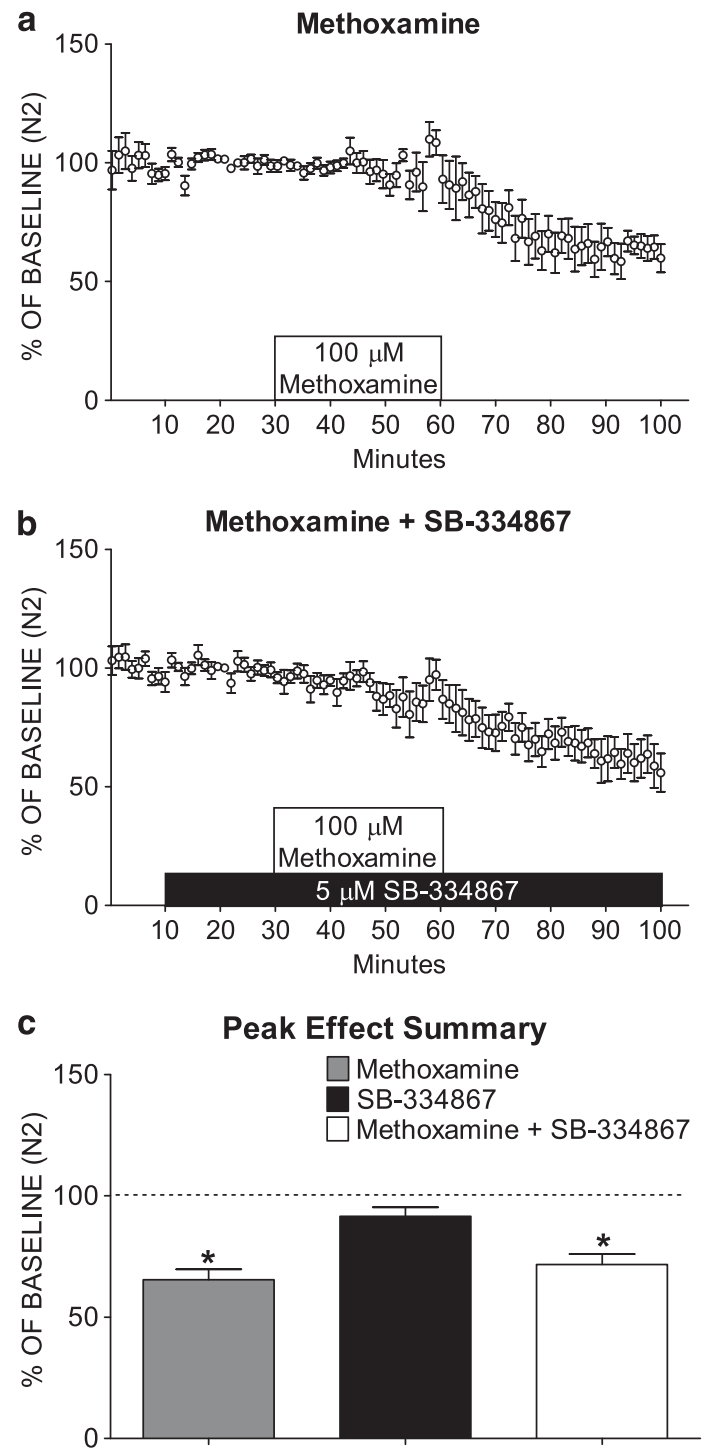

Figure $6 \quad \alpha_{1}$-AR-induced Depression of Excitatory Transmission in the dIBNST is Not Blocked by an OX, R Antagonist. Extracellular field potential recordings of excitatory transmission in the dIBNST (a) $100 \mu \mathrm{M}$ methoxamine; $n=6$ slices from four mice; (b) $100 \mu \mathrm{M}$ methoxamine in the presence of $5 \mu \mathrm{M}$ SB-334867; $n=7$ slices from four mice; (c) summary of 86-90 min for methoxamine and SB-334867+ methoxamine. Data are represented as mean $\pm \mathrm{SEM}$, $* p<0.05, n=5-7$ slices per group.

values for $\alpha_{2 \mathrm{~A}}-A R-W T: t=4.7,{ }^{\star} p<0.01, n=51$, Figure 7a; post-test preference expressed compared with pre-test values for $\alpha_{2 \mathrm{~A}}-A R-K O: t=8.9,{ }^{\star} p<0.01, n=32$, Figure $\left.7 \mathrm{a}\right)$. The magnitude of preference expressed did not differ between $\alpha_{2 \mathrm{~A}}$-AR-WT and $\alpha_{2 \mathrm{~A}}$-AR-KO mice. $\left(t_{81}=1.1, p=\right.$ n.s., Figure 7a). In the WT mice cohort, mice were assigned to one of four groups and treated with yohimbine $30 \mathrm{~min}$ before the extinction session $(5 \mathrm{mg} / \mathrm{kg}$; WT-YOH), SB-334867 $1 \mathrm{~h}$ before the extinction session $(15 \mathrm{mg} / \mathrm{kg}$; WT-SB), saline $1 \mathrm{~h}$ and $30 \mathrm{~min}$ before the extinction sessions (WT-Sal) or mice pre-treated with SB-334867 $1 \mathrm{~h}$ before and yohimbine $30 \mathrm{~min}$ before the extinction sessions (WT-SB-YOH). Doses used for yohimbine and SB-334867 were determined based on previous studies (Davis et al, 2008; Richards et al, 2008). In WT mice, two-way ANOVA RM revealed a significant effect (Figure $7 \mathrm{~b})$ of time $\left(\mathrm{F}_{5,260}=19.89\right)$, treatment $\left(\mathrm{F}_{3,260}=2.92\right)$,
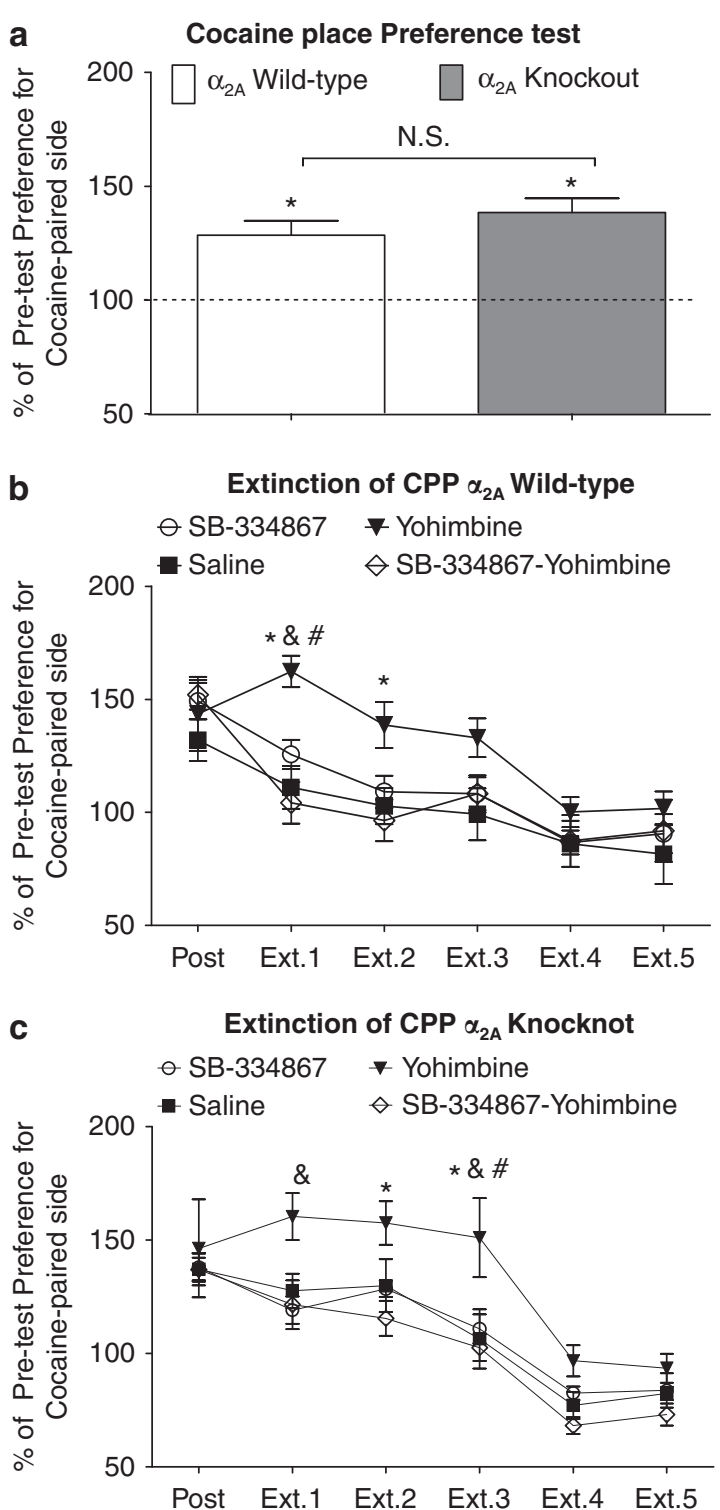

Figure $7 \mathrm{O}, \mathrm{R}$ antagonist, SB-334867, blocks yohimbine-induced impairment of extinction of cocaine-CPP in $\alpha 2_{A}$-AR wild-type and knockout mice. Magnitude of cocaine place preference assessed in a drug-free state during the pre and post preference test. All mice were conditioned with a $20 \mathrm{mg} / \mathrm{kg}$ dose of cocaine to the cocaine paired side (see Patients and Methods for additional details). (a) $\alpha_{2 A}-A R$ wild-type and knockout mice display cocaine-CPP. (b) Mice treated with yohimbine ( $5 \mathrm{mg} / \mathrm{kg}$; WT-Yoh) display impaired extinction of cocaine-CPP on extinction (Ext) days I and 2 but not on extinction days 3, 4, and 5. SB-334867 (I $5 \mathrm{mg} / \mathrm{kg}$; WT-SB) and SB-334867 and yohimbine (5 and I 5 mg/kg respectively; WT-SB-Yoh) mice display levels similar to saline (WT-Sal) mice on all extinction days. (c) Mice treated with yohimbine $(5 \mathrm{mg} / \mathrm{kg}$; $\mathrm{KO}-\mathrm{Yoh})$ display impaired extinction of cocaine-CPP on extinction (Ext) days I, 2, and 3 but not on extinction days 4 and 5. SB-334867 ( $15 \mathrm{mg} / \mathrm{kg} ; \mathrm{KO}-\mathrm{SB})$ and SB-334867 and yohimbine $(5 \mathrm{mg} / \mathrm{kg}$ and $15 \mathrm{mg} / \mathrm{kg}$ respectively; $\mathrm{KO}-\mathrm{SB}-Y$ oh) mice display levels similar to saline (KO-Sal) mice on all extinction days. Data are represented as mean \pm SEM. ${ }^{*} p<0.05$ when $\mathrm{YOH}$ group is significantly different from SB-YOH, ${ }^{\#} p<0.05$ when $\mathrm{YOH}$ group is significantly different from SAL, \& $p<0.05$ when $\mathrm{YOH}$ group is significantly different from SB group.

and time $\mathrm{x}$ treatment interaction $\left(\mathrm{F}_{15,260}=1.76\right)$. Post-hoc analysis revealed a significant effect of WT-YOH on extinction day one compared to WT-SB-YOH $(\mathrm{t}=3.867$; 
$\left.{ }^{*} p<0.05\right), \quad$ WT-SAL $\quad\left(\mathrm{t}=3.174 ; \quad{ }^{*} p<0.05\right)$, and WT-SB $\left(\mathrm{t}=2.689 ;{ }^{\circledR} p<0.05\right)$ and a significant effect of WT-YOH on extinction day 2 compared to WT-SB-YOH $(\mathrm{t}=2.859$; $\left.{ }^{*} p<0.05\right)$. No differences were found on distance traveled in any $\alpha_{2 \mathrm{~A}}$-AR WT group tested during extinction days $1-5$ (data not shown). These results demonstrate that systemic administration of an antagonist of the $\mathrm{OX}_{1} \mathrm{R}$ prevents yohimbine-mediated impairment of extinction of cocaine$\mathrm{CPP}$, yet the $\mathrm{OX}_{1} \mathrm{R}$ alone had no effect on the rate of extinction.

Given the putative role of the $\alpha_{2}$-AR in mediating the anxiogenic and drug-seeking related effects of yohimbine, we next investigated if an antagonist of the $\mathrm{OX}_{1} \mathrm{R}$ could still alter the yohimbine-mediated increase in time spent in the chamber previously associated with cocaine in mice lacking the $\alpha_{2 \mathrm{~A}}-\mathrm{AR}$. In the $\alpha_{2 \mathrm{~A}}-\mathrm{AR}-\mathrm{KO}$ cohort, mice were assigned to 1 of 4 groups and treated with yohimbine $30 \mathrm{~min}$ before the extinction session $(5 \mathrm{mg} / \mathrm{kg}$; KO-YOH), SB-334867 $1 \mathrm{~h}$ before the extinction session $(15 \mathrm{mg} / \mathrm{kg}$; KO-SB), saline $1 \mathrm{~h}$ and $30 \mathrm{~min}$ prior (KO-Sal) or mice pre-treated with SB-334867 $1 \mathrm{~h}$ prior and yohimbine $30 \mathrm{~min}$ before the extinction sessions (KO-SB-YOH). In KO mice, two-way ANOVA RM revealed a significant effect (Figure $7 \mathrm{c}$ ) of time $\left(\mathrm{F}_{5,129}=42.50\right)$, treatment $\left(\mathrm{F}_{3,129}=5.61\right)$, but not time $\mathrm{x}$ treatment interaction. Post-hoc analysis revealed a significant effect of $\mathrm{KO}-\mathrm{YOH}$ on extinction day one compared to KO-SB-YOH $(\mathrm{t}=4.291$; $\left.{ }^{*} p<0.05\right)$, and $\mathrm{KO}-\mathrm{SB}\left(\mathrm{t}=3.1 ;{ }^{*} p<0.05\right) ; \mathrm{KO}-\mathrm{YOH}$ on extinction day two compared to KO-SB-YOH $(\mathrm{t}=3.0351$; $\left.{ }^{*} p<0.05\right)$; $\mathrm{KO}-\mathrm{YOH}$ on extinction day three compared to KO-SB-YOH $\quad\left(\mathrm{t}=3.782 ; \quad{ }^{*} p<0.05\right), \quad$ KO-SAL $\quad(\mathrm{t}=3.346$; $\left.{ }^{\#} p<0.05\right)$, and KO-SB $\left(\mathrm{t}=3.015 ;{ }^{*} p<0.05\right)$. No differences were found on distance traveled in any $\alpha_{2 \mathrm{~A}}$-AR wild-type group tested during extinction days 1-5 (data not shown). Taken together, these results demonstrate that an $\mathrm{OX}_{1} \mathrm{R}$ antagonist can prevent yohimbine-induced impairment of extinction, both in wild-type and $\alpha_{2 \mathrm{~A}}-\mathrm{AR}-\mathrm{KO}$ mice.

\section{DISCUSSION}

We found that yohimbine depresses excitatory transmission in the dlBNST via $\mathrm{OX}_{1} \mathrm{R}$-dependent signaling, and this depressant effect was blocked both by an $\mathrm{OX}_{1} \mathrm{R}$ and a novel dual $\mathrm{OX}_{1} \mathrm{R} / \mathrm{OX}_{2} \mathrm{R}$ antagonist, but not antagonists of $\alpha_{1}$-AR and $\mathrm{CRFR}_{1}$, nor mimicked by a norepinephrine transporter blocker. Moreover, the depressant effects of yohimbine on excitatory transmission in the BNST were mimicked by orexin $\mathrm{A}$ acting at the $\mathrm{OX}_{1} \mathrm{R}$ but not $\mathrm{OX}_{2} \mathrm{R}$, demonstrating a novel action of orexin in the BNST. Additionally, we found that yohimbine did not activate $\mathrm{OX}_{1} \mathrm{Rs}$ in a stable cell line, and yohimbine depression of excitatory transmission was absent in slices prepared from OX-KO mice. Yohimbine likely depresses excitatory transmission in BNST through orexin-dependent activation of $\mathrm{OX}_{1} \mathrm{R}$ to decrease glutamate release probability, as whole-cell recordings demonstrated an $\mathrm{OX}_{1} \mathrm{R}$-dependent increase in both $\mathrm{PPR}$ and $\mathrm{CV}$. In parallel, we find that the ability of yohimbine to impair extinction of cocaine-CPP in $\alpha_{2 \mathrm{~A}}-\mathrm{AR}-\mathrm{WT}$ and $\alpha_{2 \mathrm{~A}}$-AR-KO mice is blocked by systemic administration of the $\mathrm{OX}_{1} \mathrm{R}$ antagonist SB-334867.

\section{Yohimbine Recruits $\mathrm{OX}_{1} \mathrm{R}$ Signaling to Depress Excitatory Transmission in the BNST}

Utilizing extracellular recordings, we replicated previous whole-cell recordings demonstrating yohimbine depresses excitatory transmission in dlBNST (Davis et al, 2008). Yohimbine-induced depression is intact in $\alpha_{2 \mathrm{~A}}-\mathrm{AR} \mathrm{KO}$ mice, suggesting an off-target action of the drug. While yohimbine could be acting through antagonism of $\alpha_{2 \mathrm{~B}}$-and/ or $\alpha_{2 c}$-AR subtypes (Altman et al, 1999), the $\alpha_{2}$-AR agonist UK 14304 depresses excitatory transmission but is attenuated rather than mimicked by the $\alpha 2-\mathrm{AR}$ antagonist, atipamezole (Davis et al, 2008; Egli et al, 2005). Furthermore, it is unlikely that the effects observed here involve autoreceptor functions of $\alpha_{2}$-AR activity, because the norepinephrine transport blocker reboxetine did not mimic yohimbine, and the $\alpha_{1}$-AR antagonist prazosin did not block it. Yohimbine is known to have relatively moderate- to high-affinity for a number of GPCRs other than $\alpha_{2}$-ARs, including serotonin $(5-\mathrm{HT})(1 \mathrm{~A}), 5-\mathrm{HT}(1 \mathrm{~B})$ receptors among others (Millan et al, 2000). Indeed, the actions of yohimbine on reinstatement of cocaine- and alcohol-seeking has been shown to involve 5HT and $\beta$-adrenergic receptors ( $\beta$-ARs) (Dzung Le et al, 2009; Fletcher et al, 2008; Sakurai et al, 1998). However, the actions of $\beta$-AR and 5HT receptor agonists on excitatory transmission in BNST differ from the known actions of yohimbine at these receptors (Guo and Rainnie, 2010; Hammack et al, 2009; Nobis et al, 2011). For example, previous work from our group demonstrated a $\beta$-AR agonist enhances excitatory transmission in BNST (Nobis et al, 2011). Moreover, a 5HT-1A and 5HT-2C agonist has no effect and a 5HT-1B agonist depresses excitatory transmission in the BNST (Guo et al, 2009; Guo and Rainnie, 2010), yet yohimbine is known to act as an antagonist at $5 \mathrm{HT}-1 \mathrm{~B}$ and has no significant affinity for $\beta$-ARs (Millan et al, 2000), suggesting a different target may better explain the effects of yohimbine in BNST.

Based on previous studies that had separately shown that the BNST is an important site for yohimbine actions in stress and anxiety-related behavior (Buffalari and See, 2010; Johnson et al, 2010), we hypothesized that yohimbine interacts with orexin signaling to alter glutamatergic transmission. Indeed, yohimbine-induced depression was sensitive to $\mathrm{OX}_{1} \mathrm{R}$ and a dual $\mathrm{Ox} 1 \mathrm{R} / \mathrm{OX}_{2} \mathrm{R}$ antagonism, and mimicked by exogenous orexin A application. Finally, an absence of yohimbine-induced depression on excitatory transmission in the Ox-KO confirms the necessity of the orexin system in mediating the effects of yohimbine on excitatory transmission in the BNST.

\section{Orexin A Depresses Excitatory Transmission in the BNST in an $\mathrm{OX}_{1} \mathrm{R}$-Dependent Manner}

Our results indicate a novel role for orexin A in depressing excitatory transmission in the dlBNST of adult mice, while studies in other brain regions have predominantly demonstrated excitatory roles (Bisetti et al, 2006; Burlet et al, 2002; Follwell and Ferguson, 2002; Hagan et al, 1999; Sakurai et al, 1998; Shin et al, 2009; Shirasaka et al, 2001; Soffin et al, 2002; Sutcliffe and de Lecea, 2000; Yang et al, 2003). This dichotomy of actions of GPCRs on neuronal function is not unusual. The Gq-linked mGluR5 and $\alpha_{1}$-AR both induce 
depression of excitatory transmission yet enhance NMDA receptor function (Grueter and Winder, 2005; Kirkwood et al, 1999; McElligott and Winder, 2009; McElligott et al, 2010). Moreover, two recent studies reported that in the hippocampus and ventrolateral periaqueductal gray (vlPAG), orexin A elicited a depression of excitatory transmission in young animals (Ho et al, 2011; Selbach et al, 2010).

\section{Yohimbine Acts Indirectly at the $\mathrm{OX}_{1} R$}

Our results with the $\mathrm{OX}_{1} \mathrm{R}$ cell line indicate that yohimbine is not a direct ligand for $\mathrm{OX}_{1} \mathrm{R}$. Indeed, a concentration of $1 \mathrm{mM}$ yohimbine and above was necessary to observe any calcium mobilization. This effect was not blocked by the $\mathrm{OX}_{1} \mathrm{R}$ antagonist, SB-334867, and was also evident in a cell line expressing $\mathrm{mGluR} 2$ rather than $\mathrm{OX}_{1} \mathrm{R}$, indicating that it was independent of $\mathrm{OX}_{1} \mathrm{R}$ signaling. It should be noted, however, that we cannot exclude the possibility that $\mathrm{OX}_{1} \mathrm{R}$ in vivo responds differently to yohimbine than in cell lines. For example, Gq-linked elevations in postsynaptic $\mathrm{Ca}^{2+}$ levels have been shown to lead to endocannabinoidmediated retrograde signaling (Wettschureck et al, 2006). Within the BNST, activation of the cannabinoid 1 receptor (CB1) depresses excitatory transmission (Grueter et al, 2006; Puente et al, 2010). As our PPR and CV analysis indicate a decrease in presynaptic glutamate release probability, future studies will investigate the potential role for CB1-mediated retrograde signaling on the $\mathrm{OX}_{1} \mathrm{R}$ dependent yohimbine-induced depression of excitatory transmission. Our results demonstrate that deletion of orexin via the use of OX-KO mice blocked the yohimbineinduced depression of excitatory transmission and it seems most likely that in the BNST yohimbine acts indirectly to promote orexin A release to influence synaptic function and impact behavior.

\section{$\mathrm{OX}_{1} \mathrm{R}$ Mediates Yohimbine-impaired Cocaine Extinction}

As we found that the depressant effects of yohimbine in the BNST require orexin signaling, we wondered whether behavioral actions of yohimbine would also require the actions of this neuropeptide. To date, studies on the role of the orexin system on cocaine relapse behavior have focused primarily on reinstatement. In the present study, we sought to investigate the potential involvement of orexin in mediating the effects of stress on cocaine extinction.

We found that systemic $\mathrm{OX}_{1} \mathrm{R}$ antagonism blunted yohimbine-impaired extinction of cocaine-CPP in $\alpha_{2 \mathrm{~A}}-\mathrm{AR}$ WT and KO mice. Consistent with our findings that the $\mathrm{OX}_{1} \mathrm{R}$ is involved in extinction of cocaine reward are reports that the $\mathrm{OX}_{1} \mathrm{R}$ mediates yohimbine-induced reinstatement of alcohol- and cocaine-seeking behavior (Buffalari and See, 2010; Zhou et al, 2011). Recent studies have also highlighted the interaction of yohimbine with non- $\mathrm{OX}_{1} \mathrm{R}$ neuropeptides, such as $\mathrm{CRFR}_{1}$ (Marinelli et al, 2007). However, given that (1) Brown et al (2009) demonstrated that a CRFR antagonist failed to block yohimbine-induced reinstatement of cocaine-seeking behavior and (2) we found no effect of the $\mathrm{CRF}_{1}$ antagonist, NBI-27914, on yohimbine-induced depression of excitatory transmission, it seems unlikely but remains to be examined the behavioral effects of $\mathrm{CRFR}_{1}$ antagonism on yohimbine-induced impairment of extinction of cocaine-CPP. Moreover, a role for norepinephrine involvement in our reported behavior also seems unlikely, as an $\mathrm{OX}_{1} \mathrm{R}$ antagonist was similarly effective at blocking yohimbine-impaired cocaine-CPP extinction in both $\alpha_{2 \mathrm{~A}}-$ AR WT and KO mice. Indeed, previous work demonstrated that the $\alpha_{2}$-AR antagonist, atipamezole, also failed to impair extinction of cocaine-CPP (Davis et al 2008). On alcohol self-administration and reinstatement, the effects of yohimbine are not mimicked by a highly selective $\alpha_{2}$-AR antagonist, RS-79948, nor were the effects of yohimbine on self-administration blocked by the $\alpha_{2}$-AR agonist clonidine (Dzung Le et al, 2009). Similarly, neither clonidine nor prazosin block yohimbine-induced reinstatement of cocaine-seeking behavior (Brown et al, 2009).

\section{Conclusions}

Taken together, these data demonstrate an important new mechanism for orexin action, and show that significant behavioral actions of yohimbine may be independent of adrenergic signaling and instead require $\mathrm{OX}_{1} \mathrm{R}$ in the BNST. Moreover, our data does not preclude the additional possibility that orexin acts upstream of yohimbine to facilitate yohimbine-induced impairment of excitatory transmission. However, our data do strongly suggest little role, if any, for the norepinephrine system in the depressant effects of yohimbine on glutamatergic transmission. Given the pivotal role stress has during withdrawal in enhancing susceptibility to cocaine-seeking behavior, our data highlight an important role for orexin in mediating stress-induced impairment of the extinction of cocaine-seeking behavior. Moreover, our data implicating a role for $\mathrm{OX}_{1} \mathrm{R}$ in stress- and reward-related cocaine extinction behavior is paralleled by changes in neuronal function in the BNST and reveals a novel action of orexin in depressing excitatory transmission, likely through a presynaptic decrease in the release probability of glutamate. Our data indicate that continued investigation of the actions of orexin on synaptic plasticity in the BNST, a region critical to the integration of stress and cocaine reward information, is clearly warranted. Moreover, as our study establishes yohimbine lacks direct agonist activity at the $\mathrm{OX}_{1} \mathrm{R}$, future studies should address the precise target(s) and underlying mechanism by which yohimbine affects orexin release and/or signaling in the dlBNST.

\section{ACKNOWLEDGEMENTS}

The behavioral data presented in this manuscript were generated at the Vanderbilt Murine Neurobehavioral Laboratory: http://kc.vanderbilt.edu/mnlcore/. We would like to thank Dr John Allison and Elana Epstein for their generous assistance and expertise. This work was supported by National Institutes of Health Grants NS07491 and MH065215-08 (KLC) and AA019455 AND DA019112 (DGW).

\section{DISCLOSURE}

The authors declare no conflict of interest. 


\section{REFERENCES}

Abercrombie ED, Keller Jr RW, Zigmond MJ (1988). Characterization of hippocampal norepinephrine release as measured by microdialysis perfusion: pharmacological and behavioral studies. Neuroscience 27: 897-904.

Aghajanian GK, VanderMaelen CP (1982). alpha 2-adrenoceptormediated hyperpolarization of locus coeruleus neurons: intracellular studies in vivo. Science 215: 1394-1396.

Altman JD, Trendelenburg AU, MacMillan L, Bernstein D, Limbird $\mathrm{L}$, Starke K et al (1999). Abnormal regulation of the sympathetic nervous system in alpha2A-adrenergic receptor knockout mice. Mol Pharmacol 56: 154-161.

Baldo BA, Daniel RA, Berridge CW, Kelley AE (2003). Overlapping distributions of orexin/hypocretin- and dopamine-betahydroxylase immunoreactive fibers in rat brain regions mediating arousal, motivation, and stress. J Comp Neurol 464: 220-237.

Banihashemi L, Rinaman L (2006). Noradrenergic inputs to the bed nucleus of the stria terminalis and paraventricular nucleus of the hypothalamus underlie hypothalamic-pituitary-adrenal axis but not hypophagic or conditioned avoidance responses to systemic yohimbine. J Neurosci (Official J Soc Neurosci) 26: 11442-11453.

Bisetti A, Cvetkovic V, Serafin M, Bayer L, Machard D, Jones BE et al (2006). Excitatory action of hypocretin/orexin on neurons of the central medial amygdala. Neuroscience 142: 999-1004.

Boutrel B, Kenny PJ, Specio SE, Martin-Fardon R, Markou A, Koob $\mathrm{GF}$ et al (2005). Role for hypocretin in mediating stress-induced reinstatement of cocaine-seeking behavior. Proc Natl Acad Sci USA 102: 19168-19173.

Brown ZJ, Tribe E, D'Souza N A, Erb S (2009). Interaction between noradrenaline and corticotrophin-releasing factor in the reinstatement of cocaine seeking in the rat. Psychopharmacology 203: $121-130$.

Buffalari DM, See RE (2010). Inactivation of the bed nucleus of the stria terminalis in an animal model of relapse: effects on conditioned cue-induced reinstatement and its enhancement by yohimbine. Psychopharmacology (Berl) 213: 19-27.

Burlet S, Tyler CJ, Leonard CS (2002). Direct and indirect excitation of laterodorsal tegmental neurons by Hypocretin/ Orexin peptides: implications for wakefulness and narcolepsy. J Neurosci 22: 2862-2872.

Cain CK, Blouin AM, Barad M (2004). Adrenergic transmission facilitates extinction of conditional fear in mice. Learn Mem 11: 179-187.

Champagne D, Beaulieu J, Drolet G (1998). CRFergic innervation of the paraventricular nucleus of the rat hypothalamus: a tracttracing study. J Neuroendocrinol 10: 119-131.

Davis AR, Shields AD, Brigman JL, Norcross M, McElligott ZA, Holmes A et al (2008). Yohimbine impairs extinction of cocaineconditioned place preference in an alpha2-adrenergic receptor independent process. Learn Mem 15: 667-676.

Dayas CV, McGranahan TM, Martin-Fardon R, Weiss F (2008). Stimuli linked to ethanol availability activate hypothalamic CART and orexin neurons in a reinstatement model of relapse. Biol Psychiatry 63: 152-157.

de Lecea L, Kilduff TS, Peyron C, Gao X, Foye PE, Danielson PE et al (1998). The hypocretins: hypothalamus-specific peptides with neuroexcitatory activity. Proc Natl Acad Sci USA 95: 322-327.

Dzung Le A, Funk D, Harding S, Juzytsch W, Fletcher PJ (2009). The role of noradrenaline and 5-hydroxytryptamine in yohimbine-induced increases in alcohol-seeking in rats. Psychopharmacology 204: 477-488.

Egli RE, Kash TL, Choo K, Savchenko V, Matthews RT, Blakely RD et al (2005). Norepinephrine modulates glutamatergic transmis- sion in the bed nucleus of the stria terminalis. Neuropsychopharmacology 30: 657-668.

Erb S, Salmaso N, Rodaros D, Stewart J (2001). A role for the CRFcontaining pathway from central nucleus of the amygdala to bed nucleus of the stria terminalis in the stress-induced reinstatement of cocaine seeking in rats. Psychopharmacology 158: $360-365$.

Espana RA, Oleson EB, Locke JL, Brookshire BR, Roberts DC, Jones SR (2010). The hypocretin-orexin system regulates cocaine self-administration via actions on the mesolimbic dopamine system. European J Neurosci 31: 336-348.

Fletcher PJ, Rizos Z, Sinyard J, Tampakeras M, Higgins GA (2008). The 5-HT2C receptor agonist Ro60-0175 reduces cocaine selfadministration and reinstatement induced by the stressor yohimbine, and contextual cues. Neuropsychopharmacology (Official Publ Am College Neuropsychopharmacol) 33: 1402-1412.

Follwell MJ, Ferguson AV (2002). Cellular mechanisms of orexin actions on paraventricular nucleus neurones in rat hypothalamus. J Physiol 545(Pt 3): 855-867.

Franklin KBJ, Paxinos G (1997). The Mouse Brain in Stereotaxic Coordinates. Academic Press, Inc.: San Diego.

Gosnell HB, Silberman Y, Grueter BA, Duvoisin RM, Raber J, Winder DG (2011). mGluR8 modulates excitatory transmission in the bed nucleus of the stria terminalis in a stress-dependent manner. Neuropsychopharmacology (Official Publ Am College Neuropsychopharmacol) 36: 1599-1607.

Grueter BA, Gosnell HB, Olsen CM, Schramm-Sapyta NL, Nekrasova T, Landreth GE et al (2006). Extracellular-signal regulated kinase 1-dependent metabotropic glutamate receptor 5 -induced long-term depression in the bed nucleus of the stria terminalis is disrupted by cocaine administration. J Neurosci (Official JSoc Neurosci) 26: 3210-3219.

Grueter BA, Winder DG (2005). Group II and III metabotropic glutamate receptors suppress excitatory synaptic transmission in the dorsolateral bed nucleus of the stria terminalis. Neuropsychopharmacology 30: 1302-1311.

Guo JD, Hammack SE, Hazra R, Levita L, Rainnie DG (2009). Bi-directional modulation of bed nucleus of stria terminalis neurons by 5-HT: molecular expression and functional properties of excitatory 5-HT receptor subtypes. Neuroscience 164: 1776-1793.

Guo JD, Rainnie DG (2010). Presynaptic 5-HT(1B) receptor-mediated serotonergic inhibition of glutamate transmission in the bed nucleus of the stria terminalis. Neuroscience 165: 1390-1401.

Hagan JJ, Leslie RA, Patel S, Evans ML, Wattam TA, Holmes S et al (1999). Orexin A activates locus coeruleus cell firing and increases arousal in the rat. Proc Natl Acad Sci USA 96: 10911-10916.

Hammack SE, Guo JD, Hazra R, Dabrowska J, Myers KM, Rainnie DG (2009). The response of neurons in the bed nucleus of the stria terminalis to serotonin: implications for anxiety. Prog Neuropsychopharmacol Biol Psychiatry 33: 1309-1320.

Harris GC, Wimmer M, Aston-Jones G (2005). A role for lateral hypothalamic orexin neurons in reward seeking. Nature 437: 556-559.

Hefner K, Whittle N, Juhasz J, Norcross M, Karlsson RM, Saksida LM et al (2008). Impaired fear extinction learning and corticoamygdala circuit abnormalities in a common genetic mouse strain. J Neurosci (Official J Soc Neurosci) 28: 8074-8085.

Hervieu GJ, Cluderay JE, Harrison DC, Roberts JC, Leslie RA (2001). Gene expression and protein distribution of the orexin-1 receptor in the rat brain and spinal cord. Neuroscience 103: 777-797.

Ho YC, Lee HJ, Tung LW, Liao YY, Fu SY, Teng SF et al (2011). Activation of orexin 1 receptors in the periaqueductal gray of male rats leads to antinociception via retrograde endocannabinoid (2-arachidonoylglycerol)-induced disinhibition. J Neurosci (Official J Soc Neurosci) 31: 14600-14610. 
Jin X, Semenova S, Yang L, Ardecky R, Sheffler DJ, Dahl R et al (2010). The mGluR2 positive allosteric modulator BINA decreases cocaine self-administration and cue-induced cocaineseeking and counteracts cocaine-induced enhancement of brain reward function in rats. Neuropsychopharmacology 35: 2021-2036.

Johnson PL, Truitt W, Fitz SD, Minick PE, Dietrich A, Sanghani S et al (2010). A key role for orexin in panic anxiety. Nat Med 16: 111-115.

Kash TL, Winder DG (2006). Neuropeptide Y and corticotropinreleasing factor bi-directionally modulate inhibitory synaptic transmission in the bed nucleus of the stria terminalis. Neuropharmacology 51: 1013-1022.

Kirkwood A, Rozas C, Kirkwood J, Perez F, Bear MF (1999). Modulation of long-term synaptic depression in visual cortex by acetylcholine and norepinephrine. J Neurosci (Official J Soc Neurosci) 19: 1599-1609.

Kupferschmidt DA, Tribe E, Erb S (2009). Effects of repeated yohimbine on the extinction and reinstatement of cocaine seeking. Pharmacol, Biochem, and Behav 91: 473-480.

Lawrence AJ, Cowen MS, Yang HJ, Chen F, Oldfield B (2006). The orexin system regulates alcohol-seeking in rats. Br J Pharmacol 148: 752-759.

Le AD, Funk D, Juzytsch W, Coen K, Navarre BM, Cifani C et al (2011). Effect of prazosin and guanfacine on stress-induced reinstatement of alcohol and food seeking in rats. Psychopharmacology 218: 89-99.

Leri F, Flores J, Rodaros D, Stewart J (2002). Blockade of stressinduced but not cocaine-induced reinstatement by infusion of noradrenergic antagonists into the bed nucleus of the stria terminalis or the central nucleus of the amygdala. $J$ Neurosci (Official J Soc Neurosci) 22: 5713-5718.

Marcus JN, Aschkenasi CJ, Lee CE, Chemelli RM, Saper CB, Yanagisawa $M$ et al (2001). Differential expression of orexin receptors 1 and 2 in the rat brain. J Comp Neurol 435: 6-25.

Marinelli PW, Funk D, Juzytsch W, Harding S, Rice KC, Shaham Y et al (2007). The CRF1 receptor antagonist antalarmin attenuates yohimbine-induced increases in operant alcohol self-administration and reinstatement of alcohol seeking in rats. Psychopharmacology (Berl) 195: 345-355.

McDougle CJ, Black JE, Malison RT, Zimmermann RC, Kosten TR, Heninger GR et al (1994). Noradrenergic dysregulation during discontinuation of cocaine use in addicts. Arch Gen Psychiatry 51: 713-719.

McElligott ZA, Klug JR, Nobis WP, Patel S, Grueter BA, Kash TL et al (2010). Distinct forms of Gq-receptor-dependent plasticity of excitatory transmission in the BNST are differentially affected by stress. Proc Natl Acad Sci USA 107: 2271-2276.

McElligott ZA, Winder DG (2008). Alpha1-adrenergic receptorinduced heterosynaptic long-term depression in the bed nucleus of the stria terminalis is disrupted in mouse models of affective disorders. Neuropsychopharmacology 33: 2313-2323.

McElligott ZA, Winder DG (2009). Modulation of glutamatergic synaptic transmission in the bed nucleus of the stria terminalis. Prog Neuro-Psychopharmacol Biol Psychiatry 33: 1329-1335.

Millan EZ, Marchant NJ, McNally GP (2011). Extinction of drug seeking. Behav Brain Res 217: 454-462.

Millan MJ, Newman-Tancredi A, Audinot V, Cussac D, Lejeune F, Nicolas JP et al (2000). Agonist and antagonist actions of yohimbine as compared to fluparoxan at alpha(2)-adrenergic receptors (AR)s, serotonin (5-HT)(1A), 5-HT(1B), 5-HT(1D) and dopamine $\mathrm{D}(2)$ and $\mathrm{D}(3)$ receptors. Significance for the modulation of frontocortical monoaminergic transmission and depressive states. Synapse 35: 79-95.

Myers EA, Banihashemi L, Rinaman L (2005). The anxiogenic drug yohimbine activates central viscerosensory circuits in rats. J Comp Neurol 492: 426-441.
Myers KM, Carlezon Jr WA (2010). Extinction of drug- and withdrawal-paired cues in animal models: relevance to the treatment of addiction. Neurosci Biobehav Rev 35: 285-302.

Niswender CM, Johnson KA, Luo Q, Ayala JE, Kim C, Conn PJ et al (2008). A novel assay of Gi/o-linked G protein-coupled receptor coupling to potassium channels provides new insights into the pharmacology of the group III metabotropic glutamate receptors. Mol Pharmacol 73: 1213-1224.

Nobis WP, Kash TL, Silberman Y, Winder DG (2011). betaAdrenergic receptors enhance excitatory transmission in the bed nucleus of the stria terminalis through a corticotrophinreleasing factor receptor-dependent and cocaine-regulated mechanism. Biol Psychiatry 69: 1083-1090.

Porter RA, Chan WN, Coulton S, Johns A, Hadley MS, Widdowson K et al (2001). 1,3-Biarylureas as selective non-peptide antagonists of the orexin-1 receptor. Bioorg Med Chem Lett 11: 1907-1910.

Puente N, Elezgarai I, Lafourcade M, Reguero L, Marsicano G, Georges $\mathrm{F}$ et al (2010). Localization and function of the cannabinoid CB1 receptor in the anterolateral bed nucleus of the stria terminalis. Plos One 5: e8869.

Richards JK, Simms JA, Steensland P, Taha SA, Borgland SL, Bonci A et al (2008). Inhibition of orexin-1/hypocretin-1 receptors inhibits yohimbine-induced reinstatement of ethanol and sucrose seeking in Long-Evans rats. Psychopharmacology (Berl) 199: 109-117.

Sakurai T, Amemiya A, Ishii M, Matsuzaki I, Chemelli RM, Tanaka $\mathrm{H}$ et al (1998). Orexins and orexin receptors: a family of hypothalamic neuropeptides and $\mathrm{G}$ protein-coupled receptors that regulate feeding behavior. Cell 92: 573-585.

Selbach O, Bohla C, Barbara A, Doreulee N, Eriksson KS, Sergeeva OA et al (2010). Orexins/hypocretins control bistability of hippocampal long-term synaptic plasticity through co-activation of multiple kinases. Acta Physiol (Oxf) 198: 277-285.

Shaham Y, Erb S, Stewart J (2000). Stress-induced relapse to heroin and cocaine seeking in rats: a review. Brain Res Brain Res Rev 33: 13-33.

Shalev U, Erb S, Shaham Y (2010). Role of CRF and other neuropeptides in stress-induced reinstatement of drug seeking. Brain Res 1314: 15-28.

Shields AD, Wang Q, Winder DG (2009). alpha2A-adrenergic receptors heterosynaptically regulate glutamatergic transmission in the bed nucleus of the stria terminalis. Neuroscience 163: 339-351.

Shin HS, Cho HS, Sung KW, Yoon BJ (2009). Orexin-A increases cell surface expression of AMPA receptors in the striatum. Biochem Biophys Res Commun 378: 409-413.

Shirasaka T, Miyahara S, Kunitake T, Jin QH, Kato K, Takasaki M et al (2001). Orexin depolarizes rat hypothalamic paraventricular nucleus neurons. Am J Physiol Regul Integr Comp Physiol 281: R1114-R1118.

Soffin EM, Evans ML, Gill CH, Harries MH, Benham CD, Davies CH (2002). SB-334867-A antagonises orexin mediated excitation in the locus coeruleus. Neuropharmacology 42: 127-133.

Starke K (2001). Presynaptic autoreceptors in the third decade: focus on alpha2-adrenoceptors. J Neurochem 78: 685-693.

Stine SM, Southwick SM, Petrakis IL, Kosten TR, Charney DS, Krystal JH (2002). Yohimbine-induced withdrawal and anxiety symptoms in opioid-dependent patients. Biol Psychiatry 51: 642-651.

Sutcliffe JG, de Lecea L (2000). The hypocretins: excitatory neuromodulatory peptides for multiple homeostatic systems, including sleep and feeding. J Neurosci Res 62: 161-168.

Weitlauf C, Egli RE, Grueter BA, Winder DG (2004). Highfrequency stimulation induces ethanol-sensitive long-term potentiation at glutamatergic synapses in the dorsolateral bed nucleus of the stria terminalis. J Neurosci 24: 5741-5747.

Wettschureck N, van der Stelt M, Tsubokawa H, Krestel H, Moers A, Petrosino S et al (2006). Forebrain-specific inactivation of $\mathrm{Gq} / \mathrm{G} 11$ family $\mathrm{G}$ proteins results in age-dependent epilepsy 
and impaired endocannabinoid formation. Mol Cell Biol 26: 5888-5894.

Willie JT, Chemelli RM, Sinton CM, Tokita S, Williams SC, Kisanuki YY et al (2003). Distinct narcolepsy syndromes in Orexin receptor-2 and Orexin null mice: molecular genetic dissection of Non-REM and REM sleep regulatory processes. Neuron 38: 715-730.
Yang B, Samson WK, Ferguson AV (2003). Excitatory effects of orexin-A on nucleus tractus solitarius neurons are mediated by phospholipase $\mathrm{C}$ and protein kinase C. J Neurosci 23: 6215-6222.

Zhou L, Ghee SM, Chan C, Lin L, Cameron MD, Kenny PJ et al (2011). Orexin-1 receptor mediation of cocaine-seeking in male and female rats. J Pharmacol Exp Ther 340: 801-809. 